\title{
NISTIR 8007
}

\section{A Review of U.S.A. Participation in ISO and IEC}

\author{
Dong Geun Choi \\ Erik Puskar
}

http://dx.doi.org/10.6028/NIST.IR.8007

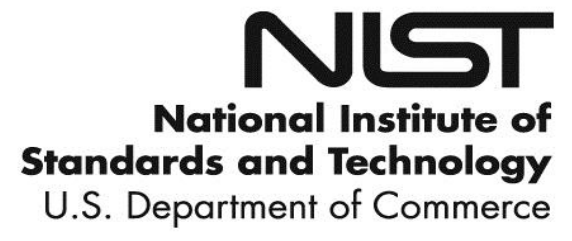




\title{
NISTIR 8007
}

\section{A Review of U.S.A. Participation in ISO and IEC}

\author{
Dong Geun Choi \\ Erik Puskar \\ Standards Coordination Office \\ Laboratory Programs
}

This publication is available free of charge from:

http://dx.doi.org/10.6028/NIST.IR.8007

June 2014

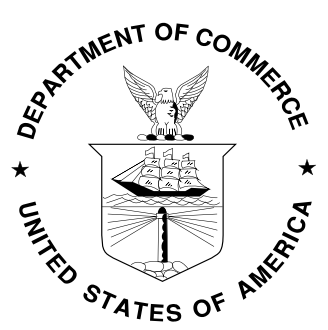

U.S. Department of Commerce Penny Pritzker, Secretary

National Institute of Standards and Technology Willie May, Acting Under Secretary of Commerce for Standards and Technology and Acting Director 


\section{Foreword}

The primary strategy for U.S.A. government engagement in standards development is "reliance on private sector leadership, supplemented by federal government contributions to discrete standardization processes as outlined in OMB Circular A-119, Federal Participation in the Development and Use of Voluntary Consensus Standards and in Conformity Assessment Activities." Apart from standards development led by the private sector, the Trade Act of 1979 requires that the U.S.A. federal government shall inform, consult and coordinate with the U.S.A. Trade Representative with respect to international standards-related activities in order to keep each adequately informed and identify activities that may substantially affect U.S.A. commerce.

Based on Section 2543 of the Trade Agreements Act of 1979², the Department of Commerce (DOC) is responsible for monitoring the representation of United States interests before international standards organizations. As an agency of DOC, the National Institute of Standards and Technology (NIST) published two specific reports for this purpose. The first report, titled 'A Review of U.S.A. Participation in International Standards Activities (NBSIR 3698)', was published in January 1988, and covered the U.S.A. participation status in International Organization for Standardization (ISO) and International Electrotechnical Commission (IEC) during 1966 to1986. The second report, 'A Review of U.S.A. Participation in ISO and IEC (NISTIR 6492),' was published 12 years later in February 2000, and covered U.S.A. participation from 1966 to 1998 with a focus on the latter years. These two reports are a few of the publicly available resources to track the history of U.S.A. participation in ISO and IEC.

For the same purpose served by the two previous reports in 1988 and 2000, this report in 2014 is designed to describe the U.S.A. participation in ISO and IEC standardization activities during the years 1966 to 2012. This report shows the U.S.A. memberships, secretariats, chairs, and convenors in standards development committees in ISO and IEC compared with previous years and other countries. Additionally, this report provides some data about the agreement-based cooperative activities of a few U.S.A.-domiciled standards developing organizations. The alignment status of American National Standards (ANS), approved by American National Standards Institute (ANSI), with ISO and IEC standards, is also included.

Disclaimer: Any mention of commercial products or organizations within this document is for information only; it does not imply recommendation or endorsement by NIST.

\section{Keywords}

U.S.A. Trade Agreement Act; WTO; TBT; Agreement on Technical Barriers to Trade; IEC; ISO; American National Standards Institute (ANSI); international standards; participation; trade; and,

\footnotetext{
${ }^{1}$ White House (January 17, 2012), Memorandum for the Heads of Executive Departments and Agencies - Principles for Federal Engagement in Standards Activities to Address National Priorities (M-12-08).

2 Trade Agreements Act of 1979 (Section 2533: Representation of United States interests before international standards organizations).
} 
United States National Committee (USNC).

\section{Table of Contents}

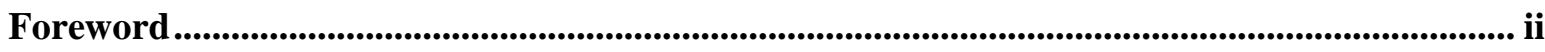

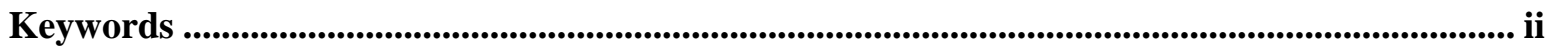

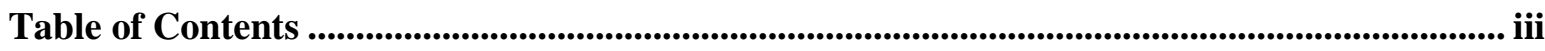

Table of Contents - Figures......................................................................................................................v

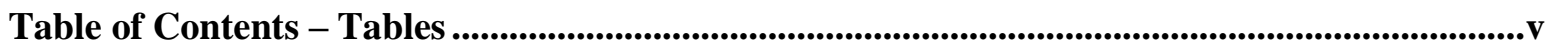

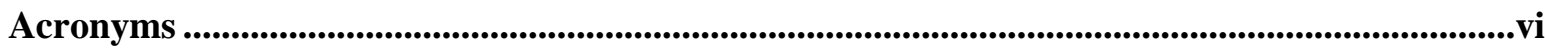

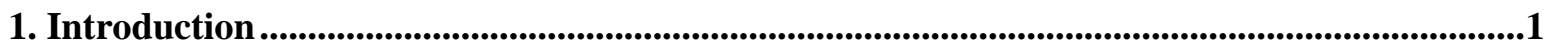

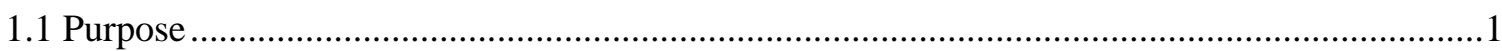

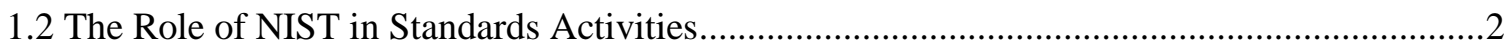

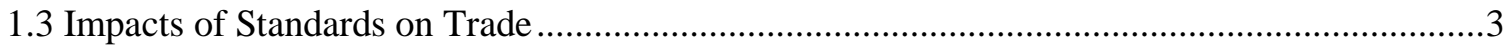

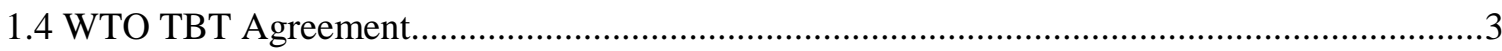

1.5 The Politics and History of International Standardization .....................................................

2. Comparison with Two Previous NIST Publications .............................................................

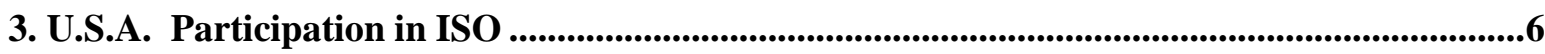

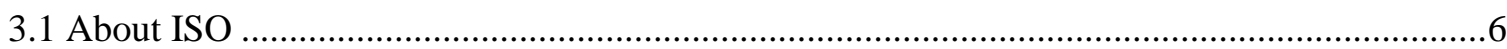

3.2 U.S.A. Participation in ISO Technical Committees and Subcommittees................................8

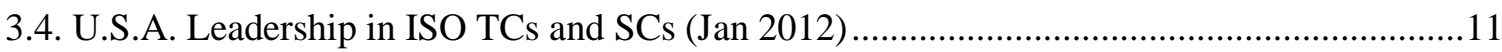

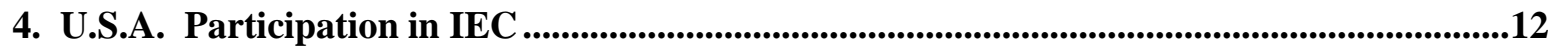

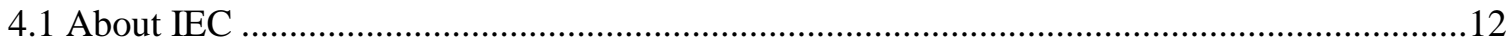

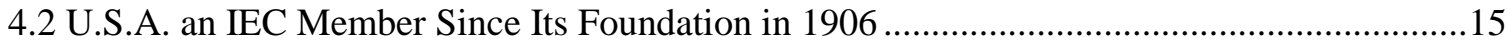

4.3 U.S.A. Participation in IEC SCs and TCs (April 2013) ........................................................16

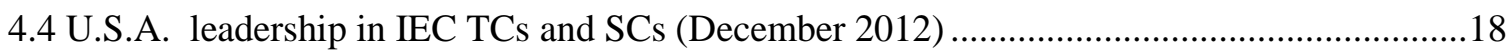

4.5 U.S.A. Number of Experts and New Proposals in 2012 ......................................................19

5. Agreement-based Participation by U.S.A.-domiciled SDOs or Consortia ..............................20

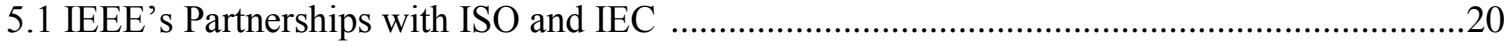

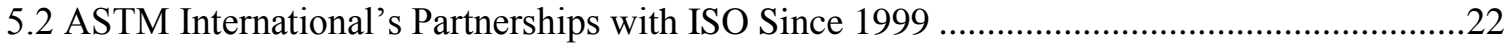

5.3 Approved PAS Submitters to JTC 1, Including some US-domiciled Consortia ......................23

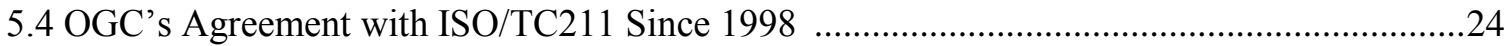


6. Use of ISO and IEC Standards in the USA

6.1 Adoption of ISO and IEC Standards as American National Standards (ANS) ......................24

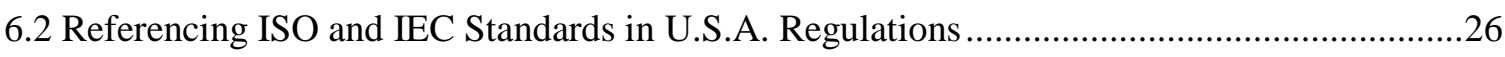

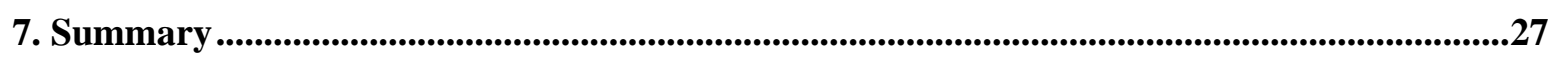

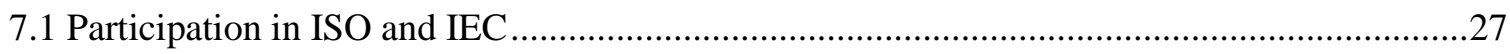

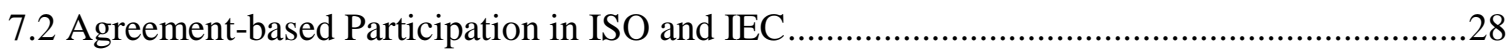

7.3 U.S.A. Standards and Regulations Aligned with ISO and IEC Standards ............................29

Annex 1. Membership Comparison of ISO, IEC, and UN (Dec 2012) .....................................31

Annex 2. List of ISO and IEC Technical Committees ..............................................................37

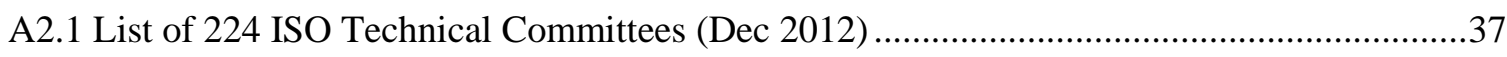

A2.2 List of 97 IEC Technical Committees (Dec 2012) ............................................................43

A2.3 List of Subcommittees in ISO/IEC JTC 1 and JPC 1 (Dec 2012) ......................................47

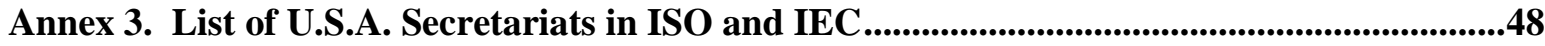

A3.1 List of 121 ISO TC/SCs Whose Secretariat is the U.S.A. (Dec 2012).................................48

A3.2. List of 24 IEC TC/SCs Whose Secretariat is the U.S.A. (Dec 2012) .................................52

Annex 4. ISO and IEC Standards Development Stages............................................................53

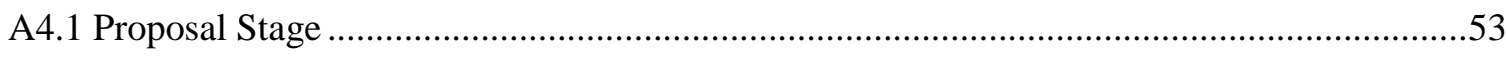

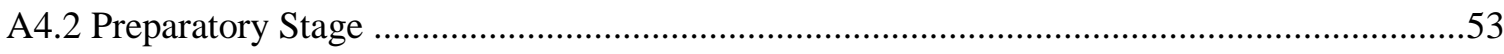

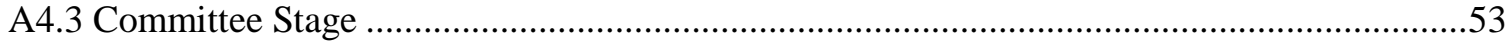

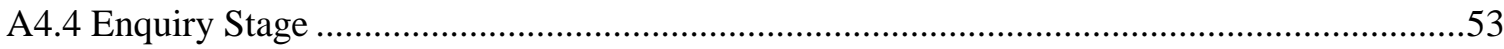

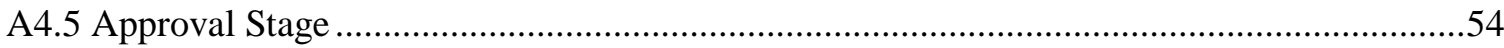

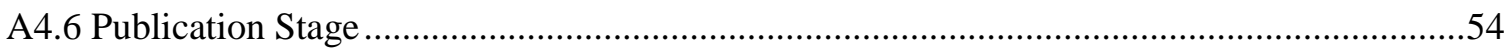

A4.7 Review of International Standards (Confirmation, Revision, Withdrawal) .........................54

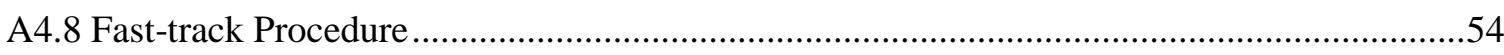

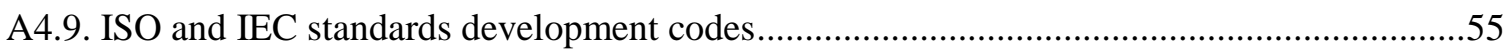

Annex 5. U.S.A. Laws Concerning NIST's Role in Standardization ..........................................56

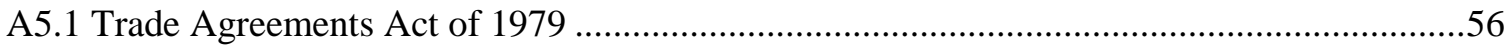

A5.2 The National Technology Transfer and Advancement Act (NTTAA) of 1995 ....................58

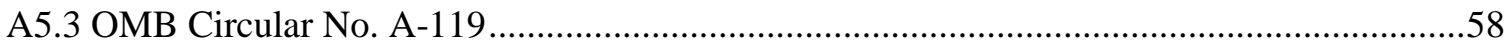

Annex 6. MOU between ANSI and NIST ..................................................................................................59

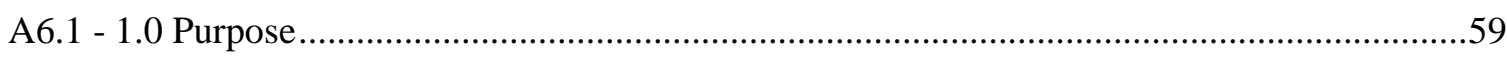

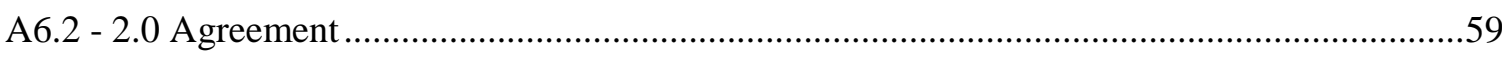




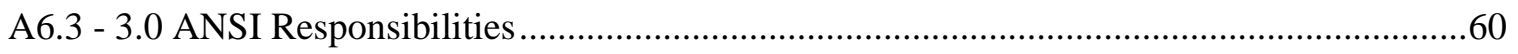

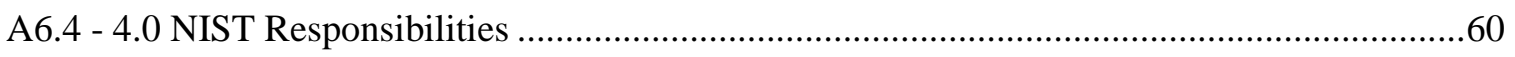

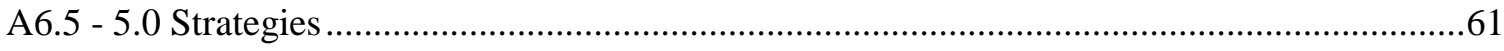

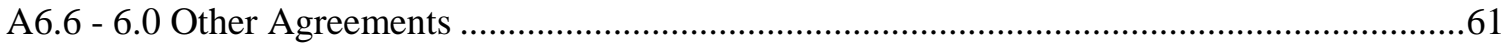

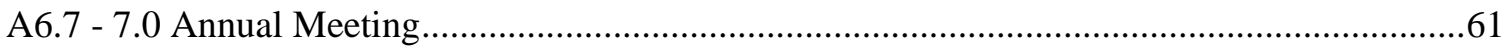

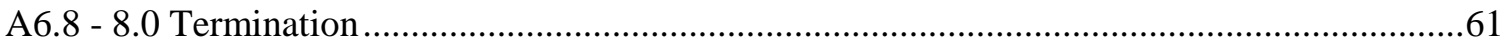

\section{Table of Contents - Figures}

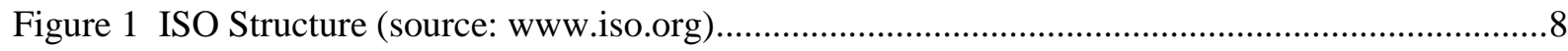

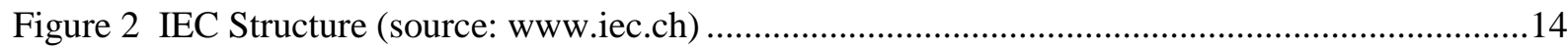

Figure 3 U.S.A. P-memberships in ISO and IEC have Increased in 1986 to 2012 ...........................27

Figure 4 U.S.A. Secretariats Increased in 1966-1998, and Declined in 1998 to 2012 .......................28

Figure 5 U.S.A. Convenor in ISO Decreased and Chair in IEC increased in 1998 to 2012 ................28

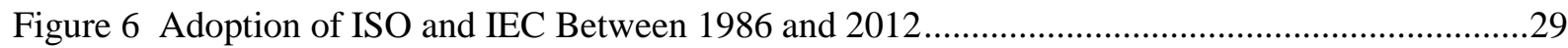

Figure 7 Incorporation by Reference of ISO and IEC Between 2002 and 2012 ................................30

\section{Table of Contents - Tables}

Table 1 Comparing Topics in three NIST reports $(1988,2000$, and 2013) .........................................6

Table 2 Top 20 Countries in ISO participation (P- and O-members) (Dec 2012) ................................10

Table 3 ISO Secretariats and Convenors over Time (1966 to 2012) ...............................................11

Table 4 Top 20 Countries Holding ISO Secretariat and Convenor Roles in 2011 ...............................12

Table 5 Number of IEC TCs and SCs as of April 2013 (source: www.iec.ch)......................................17

Table 6 Top 20 Countries in IEC P-memberships (Dec 2012) .........................................................17

Table 7 Top 15 Countries in IEC Secretariats and Chairs in Sep 2012 ..............................................18

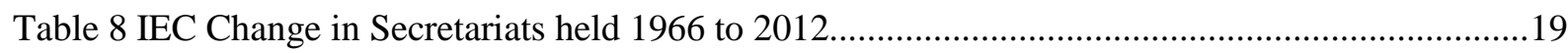

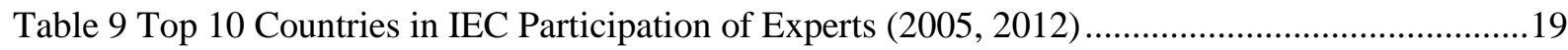

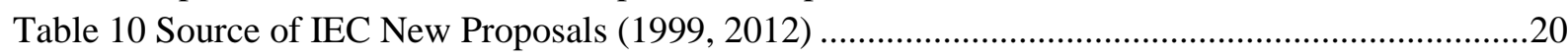

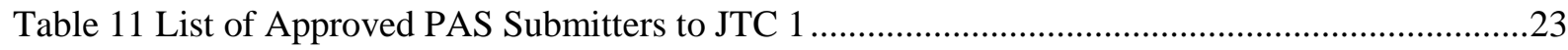

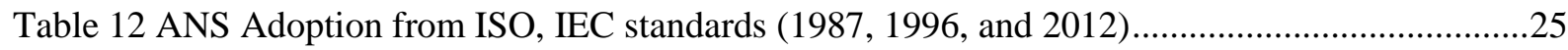

Table 13 ISO and IEC Standards Incorporated by Reference in the U.S.A. regulations ......................27

Table 14 Agreement-based Participation in ISO and IEC ............................................................29 


\section{Acronyms}

\begin{tabular}{|c|c|}
\hline ACRONYMS & DESCRIPTIONS (Country or Organization) \\
\hline ABNT & Brazilian Technical Standards Association (Brazil) \\
\hline AENOR & Asociación Española de Normalización y Certificación (Spain) \\
\hline AFNOR & Association française de normalisation (France) \\
\hline ANS & American National Standard (USA) \\
\hline ANSI & American National Standards Institute (USA) \\
\hline API & American Petroleum Institute \\
\hline ASI & Austrian Standards Institute (Austria) \\
\hline ASRO & Romanian Standards Association (Romania) \\
\hline ASTM & ASTM International \\
\hline BEC & Belgian Electrotechnical Committee (Belgium) \\
\hline BIS & Bureau of Indian Standards (India) \\
\hline BSI & British Standards Institution (UK) \\
\hline CEI & Comitato Elettrotecnico Italiano (Italy) \\
\hline CES & Swiss Electrotechnical Committee (Switzerland) \\
\hline CFR & Code of Federal Regulations (USA) \\
\hline DIN & German Institute for Standardization (Germany) \\
\hline DKE & Deutsche Kommission Elektrotechnik Elektronik Informationstechnik (Germany) \\
\hline DMTF & Distributed Management Task Force, Inc. \\
\hline DS & Danish Standards Foundation (Denmark) \\
\hline GOST R & Federal Agency on Technical Regulating and Metrology (Russia) \\
\hline IEC & International Electrotechnical Commission \\
\hline IEC CAB & IEC Conformity Assessment Board \\
\hline IEC CB & IEC Council Board \\
\hline IEC CO & IEC Central Office \\
\hline IEC EXCO & IEC Executive Committee \\
\hline IEC MSB & IEC Market Strategy Board \\
\hline
\end{tabular}




\begin{tabular}{|c|c|}
\hline IEC NC & IEC National Committee \\
\hline IEC SMB & IEC Standardization Management Board \\
\hline IEEE & Institute of Electrical and Electronics Engineers \\
\hline ISO & International Organization for Standardization \\
\hline ISO CASCO & ISO Committee on Conformity Assessment \\
\hline ISO COPOLCO & ISO Committee on Consumer Policy \\
\hline ISO CS & ISO Central Secretariat \\
\hline ISO CSC & ISO Council Standing Committee \\
\hline ISO DEVCO & ISO Committee on Developing Country Matters \\
\hline ISO GA & ISO General Assembly \\
\hline ISO MB & ISO Member Body \\
\hline ISO PDCs & ISO Policy Development Committees \\
\hline ISO TMB & ISO Technology Management Board \\
\hline JISC & Japanese Industrial Standards Committee (Japan) \\
\hline KATS & Korean Agency for Technology and Standards (Korea) \\
\hline NBN & Bureau voor Normalisatie/Bureau de Normalisation (Belgium) \\
\hline NEN & Netherlands Standardization Institute (Netherlands) \\
\hline NIST & National Institute of Standards and Technology (USA) \\
\hline OASIS & Organization for the Advancement of Structured Information Standards \\
\hline OGC & Open Geospatial Consortium (USA) \\
\hline O-member & Observer Member (ISO, IEC) \\
\hline OMG & Object Management Group \\
\hline OVE & Oesterreichischer Verband für Elektrotechnik (Austria) \\
\hline PKN & Polish Committee for Standardization (Poland) \\
\hline P-member & Participating Member (ISO, IEC) \\
\hline PSDO & Partner Standards Development Organization (ISO) \\
\hline SA & Standards Australia (Australia) \\
\hline SABS & South African Bureau of Standards (South Africa) \\
\hline SAC & Standardization Administration of China (China) \\
\hline SC & Subcommittee (ISO, IEC) \\
\hline SCC & Standards Council of Canada (Canada) \\
\hline
\end{tabular}




\begin{tabular}{ll}
\hline SEK & SEK Svensk Elstandard (Sweden) \\
SESKO & Finnish Electrotechnical Standards Association (Finland) \\
\hline SFS & Finnish Standards Association (Finland) \\
SIBR & Standards Incorporated by Reference (name of database, USA) \\
SIS & Swedish Standards Institute (Sweden) \\
SN & Standards Norway (Norway) \\
SNIA & Advancing Storage and Information Technology \\
SNV & Swiss Association for Standardization (Switzerland) \\
\hline TA & Technical Advisor (USNC for IEC) \\
TAG & Technical Advisory Group (ANSI/USNC for ISO and IEC) (USA) \\
TC & Technical Committee (ISO, IEC) \\
TCG & Trusted Computing Group \\
\hline UL & Underwriters Laboratories \\
UNI & Ente Nazionale Italiano di Unificazione (Italy) \\
\hline UNMZ & Czech Office for Standards, Metrology and Testing (Czech Republic) \\
UPnP Forum & Universal Plug and Play Forum \\
USNC & United States National Committee (for IEC) (USA) \\
UTE & Union Technique de L'Electricite (France) \\
W3C & World Wide Web Consortium \\
\hline WG & \\
\hline
\end{tabular}




\section{Introduction}

\subsection{Purpose}

This report presents historical information on the extent of U.S.A. participation and leadership roles in two private-sector international standardization bodies, perspectives on the organizations involved, the present role of international standards in world trade, and the correlation between the U.S.A. position in international standardization activities and world trade.

This publication serves as an update to the original NBSIR 88-3698, A Review of U.S.A. Participation in International Standards Activities, as well as NISTIR 6492, A Review of U.S.A. Participation in the International Organization for Standardization (ISO) and the International Electrotechnical Commission (IEC). It focuses on U.S.A. participation in technical committees (TC) and sub-committees (SC) within two private-sector international standards development organizations, namely ISO and IEC. Due to the volume of information involved, this publication does not address U.S.A. participation in any of the other activities within each of these organizations (e.g., the Committee on Conformity Assessment and the Committee on Consumer Policy in ISO, conformity assessment schemes in IEC). Specific mention is also made of the World Trade Organization's (WTO) Agreement on Technical Barriers to Trade. It should be noted that some U.S.A.-based standards developers have increased their international presence over this time period. The U.S.A. involvement with these developers may be more robust and may share common goals with regards to standards development.

U.S.A. participation in private-sector international standardization activities is voluntary. Direct involvement and payment of the associated expenses depends upon the perceived interests of the industries that may be affected by resultant standards. Consequently, some U.S.A. companies and industries have been very active in international standards-making committees, whereas others have not participated at all. The objective of this study was to collect, analyze, and present data that might summarize the extent of past and present U.S.A. participation in the activities of ISO and IEC over the 46-year period from 1966 to 2012. This information can help readers assess whether U.S.A. involvement and leadership activities are sufficient and what, if any, strategies or actions are necessary to strengthen the U.S.A. position in these organizations.

The following sections describe various NIST responsibilities, the significance of international standards in world trade, background on ISO and IEC, and how the United States is represented in those bodies.

Separate sections briefly describe the WTO Agreement on Technical Barriers to Trade and Annex 3 of that Agreement, the Code of Good Practice for the Preparation, Adoption and Application of Standards. A review of U.S.A. participation levels in ISO and IEC over the 46-year period from 1966 to 2012 is provided, followed by a comparison of U.S.A. exports with U.S.A. participation in ISO and IEC. 


\subsection{The Role of NIST in Standards Activities ${ }^{3}$}

Title IV, Section 413 of the Trade Agreements Act of 1979 (19 U.S.A.C. 2531-2573), P.L. 96-39, authorized the implementation of all agreements negotiated during the General Agreement on Tariffs and Trade (GATT) Tokyo Round, including those relating to non-tariff barriers. Section 413 of the Act directs the Secretaries of Commerce and Agriculture to ensure that they are kept informed of the adequacy of representation in international standards-related activities, to identify any activities that might substantially affect the commerce of the United States, and to coordinate with the Special Representative (the Office of the United States Trade Representative, USTR) with respect to international standards-related activities. USTR is responsible for coordinating U.S.A. discussions and negotiations with other countries with respect to standards-related activities.

Title IV also specifies that the U.S.A. should be represented in non-treaty or private international standards organizations (e.g., ISO and IEC) by a recognized "organization member." Responsibility rests with the Secretaries of Commerce and Agriculture to determine and ensure that U.S.A. interests are being adequately represented and that U.S.A. commerce is not adversely affected by that organization member's participation in private international standards organizations. There are no guidelines or definitions given for what is deemed to be adequate representation of U.S.A. interests. ANSI serves as the U.S.A. member body to ISO and, through its U.S.A. National Committee, to IEC.

Within NIST, the Standards Coordination Office is responsible for carrying out several Title IV functions. These include maintaining an inquiry point on standards, conducting conformity assessments and technical regulations, and monitoring the adequacy of U.S.A. representation in private international standards activities, particularly with regard to the potential impact on international trade. The 1994 revision of the Trade Agreements Act (P.L. 103-465), also entitled the Uruguay Round Agreements Act, did not amend these responsibilities.

In addition to its responsibilities under the Trade Agreements Act, NIST serves as a coordinator of standardsrelated activities within the federal government as directed by OMB Circular A-119, which serves as implementation guidance for the National Technology Transfer and Advancement Act (NTTAA) of 1995 (P.L. 104-113).

To ensure a coordinated effort between the public and private sectors in both domestic and non-treaty international standards activities, NIST and ANSI signed a Memorandum of Understanding (MOU) ${ }^{4}$. Revised and renewed in 2000, this MOU states that NIST and ANSI will serve as links between privatesector standards and conformity assessment interests and government interests. The ultimate objective of this cooperative effort is to enhance and strengthen the national voluntary consensus standards system of the United States while supporting continued U.S.A. competitiveness and economic growth. Other government agencies, U.S.A. and non-U.S.A.-based international standards developing organizations (SDOs), trade associations, and companies are members of ANSI. Representatives of these organizations participate in various ANSI fora which are, in part, responsible for determining ANSI policy and structure. These fora also

\footnotetext{
${ }^{3}$ The U.S. Laws concerned with NIST's role for standardization are summarized in Annex 5.

${ }^{4}$ Annex 6 contains the full text of the MOU between ANSI and NIST.
} 
serve as mechanisms that facilitate discussion of current issues of interest.

\subsection{Impacts of Standards on Trade}

Standards are more important today than ever before. In the international marketplace, standards developed through voluntary processes are highly desirable because they represent a broad-based consensus of all interested parties, including producers (exporters), users (importers), governments, consumers, and academia. Nations that actively participate in developing international standards may be able to influence the provisions to favor their own products or those that they prefer for some reason. Since trading countries competing in the global marketplace are inclined to be aggressive in exploiting every opportunity to favor these products through the standards development process, it seems incumbent on the United States to participate vigorously in international standardization activities if it intends to maintain existing trade outlets and find new markets.

\subsection{WTO TBT Agreement}

The provisions of the Agreement on Technical Barriers to Trade (TBT Agreement) and of the Code of Good Practice for the Adoption, Application and Preparation of Standards (Code) have important implications for ISO and IEC member bodies.

Specific provisions under the TBT Agreement pertain to technical regulations, standards, conformity assessment practices, notification requirements, and standards developing bodies. In the area of technical regulations and standards, the TBT Agreement states that members should:

- accord the same treatment to imported products as like products of national origin;

- accord the same treatment to all like imported products, regardless of origin;

- ensure that any technical regulations and standards used to protect human, animal, or plant life or health or the environment are not more trade-restrictive than necessary;

- use, in part or in whole, relevant international standards as a basis for technical regulations whenever possible;

- participate in relevant international standards bodies to develop and adopt appropriate technical regulations and standards;

- recognize technical regulations of other members as equivalent provided these regulations meet the objectives of their own regulations;

- emphasize product performance requirements rather than design or descriptive requirements, and

- notify other members of proposed technical regulations and standards that might significantly affect trade.

Annex 3 of the TBT Agreement contains the Code. The Code is open to acceptance by any standardizing body within the territory of a WTO Member and outlines general guidelines for the preparation and use of standards. The Code encourages standards bodies to operate in a transparent manner, ensure nondiscrimination toward imported products, and align national standards with international standards whenever possible. Adoption of the Code is voluntary, but more than 100 standards bodies currently adhere to the Code. In the United States, ANSI is a signatory to the Code on behalf of its over 200 standards- 
developing members.

\subsection{The Politics and History of International Standardization}

International trade is one of the most important factors in the growth of the world economy. Important objectives of international standardization and related activities are to facilitate trade and the exchange of goods and services at the international level and to promote cooperation in the areas affected by international standards.

Formal international standardization started over one hundred years ago in the electrotechnical field with the founding of the IEC in 1906. While some attempts were made in the 1930s to develop international standards in other fields, it was not until after World War II that the United Nations Standards Coordinating Committee, established by the United States, Great Britain, and Canada, provided the leadership that resulted in the formation of ISO in 1946.

During the 1950s and 1960s, international standardization work focused almost entirely on the development of international agreements on basic mechanics, such as screw threads, roller bearings, pipe sizes, shafts, couplings, and power transmissions. These early efforts addressed issues primarily related to international harmonization for interchangeability, vocabularies, and standards for units and symbols. In the 1960s and 1970s, there was an increase in using international standards in lieu of national standards. In the 1980s and 1990s, robust standardization work supporting the introduction of information and communications technologies was launched.

Concurrent with this evolution in standardization was a growing recognition of the role that standards and standards-related issues play in trade. It was recognized that the negotiation and adoption of technical standards for all classes of products and services can lead to the formation of economic and political coalitions among nations and regions and market segmentation among major producers. National and regional groups motivated by competing interests can use regulations and standards for political purposes.

Indeed, a General Agreement on Tariffs and Trade (GATT) working group concluded that technical barriers, such as standards, was the largest category of non-tariff measures faced by exporters. Voluntary adoption of the Standards Code to the GATT in 1979 reflected a growing acceptance of international standards for all classes of finished products, materials, and services.

With the establishment of the World Trade Organization in 1995 and the adoption of the Agreement on Technical Barriers to Trade, an integral part of the WTO Agreement, the importance of technical regulations, standards, and conformity assessments to trade was called out. All WTO members, 159 countries as of March 2013, are responsible for adhering to the provisions of the TBT Agreement to ensure that regulations, standards, and conformity assessment procedures do not create unnecessary obstacles to trade.

Three well-known standards development organizations operating in the international arena are ISO, IEC, and the International Telecommunication Union (ITU). ISO and IEC form the world's largest nongovernmental forum for voluntary industrial and technical collaboration at the international level. Collectively, ISO and IEC are responsible for the development of over 25,000 international standards 
in a wide variety of technical and business sectors. The third organization, the ITU, a treaty organization, is the United Nations specialized agency for information and communications technologies. U.S.A. participation in the ITU is coordinated by the U.S.A. Department of State. More information can be found at http://www.itu.int/en/Pages/default.aspx.

\section{Comparison with Two Previous NIST Publications}

This report is a successor of two previous NIST reports published in February 1988 and January 2000. The 1988 report, NBSIR 3698, describes the role of international standards, their increasingly significant importance in world trade, and the extent of past and current U.S.A. participation in the two major international standardization bodies: ISO and IEC. The degree of U.S.A. participation covers the 20-year period 1966 to 1986. The 2000 report, NISTIR 6492, describes the role of international standards, their importance in world trade, and the extent of U.S.A. participation in ISO and IEC over the period from 1966 to 1998 (with a focus on 1986 to 1998). Mention is also made of the WTO's Agreement on Technical Barriers to Trade.

This 2014 report, in principal, is an update of the two previous reports, covering U.S.A. participation status in ISO and IEC for the period from 1966 to 2012. The chapter for comparison of U.S.A. exports with U.S.A. participation in ISO and IEC is skipped because the correlation analysis was relatively uncertain. A new chapter included in this report, not existing in previous two reports, is Chapter 5, 'Agreement-Based Participation by US-Domiciled SDOs'. This chapter shows three examples of joint development or adoption of mutual standards by IEEE, ASTM International, and Open Geospatial Consortium (OGC). Another chapter included in the 1988 report but excluded from the 2000 report is Chapter 6, 'Alignment with ISO and IEC standards in the USA.' This chapter reviews the adoption or alignment of ISO and IEC standards as ANSI approved ANS. A comparison of topics of the reports in 1988, 2000, and 2013 is provided below in Table 1. 
Table 1 Comparing Topics in Three NIST Reports $(1988,2000,2013)$

\begin{tabular}{llll}
\hline Contents & $\begin{array}{l}\mathbf{1 9 8 8} \\
\text { report }\end{array}$ & $\begin{array}{l}\mathbf{2 0 0 0} \\
\text { Report }\end{array}$ & $\begin{array}{l}\mathbf{2 0 1 3} \\
\text { Report }\end{array}$ \\
\hline Data Period & 1966 to & 1966 to & 1966 to \\
& 1986 & 1998 & $2012^{5}$ \\
\hline $\begin{array}{l}\text { Introduction, Background, } \\
\text { ISO, IEC, WTO/TBT, Trade Agreement Act }\end{array}$ & Yes & Yes & Yes \\
$\begin{array}{l}\text { ISO: membership, secretariat, convenor } \\
\text { IEC: membership, secretariat, chair }\end{array}$ & Yes & Yes & Yes \\
$\begin{array}{l}\text { Agreement-based participation in ISO, IEC } \\
\text { Alignment of ISO, IEC standards with ANS (ANSI) }\end{array}$ & Yes & Nes & Yes \\
$\begin{array}{l}\text { Incorporation of ISO, IEC standards in the U.S.A. } \\
\text { regulation } \\
\text { Comparison of Export with Participation in ISO/IEC }\end{array}$ & No & No & $\begin{array}{l}\text { Yes } \\
\text { (new) }\end{array}$ \\
\hline
\end{tabular}

\section{U.S.A. Participation in ISO}

\subsection{About ISO}

\subsubsection{ISO Activities Since 19476}

ISO is a not-for-profit, non-governmental organization, founded in 1947. ISO originated from the union of two organizations, ISA (International Federation of the National Standardizing Associations) and UNSCC (United Nations Standards Coordinating Committee). After the union of the ISA (International Federation of the National Standardizing Associations) and the UNSCC (United Nations Standards Coordinating Committee), ISO was created through discussions held at a conference in London in October 1946, which included participation by 65 delegates from 25 national standards organizations.

The mission of ISO is "to promote the development of standardization and related activities in the world with a view to facilitating the international exchange of goods and services, and to developing cooperation in the spheres of intellectual, scientific, technological and economic activity." The first ISO standard was published in 1951. Upon its establishment in 1947, ISO membership consisted of 27 national standards bodies; at present, ISO is comprised of standards bodies from over 130 countries, of which 90 are participating member bodies, 36 are correspondent members, and 7 are subscriber members. There are 16 correspondent members that do not participate in technical work and do not have voting rights, but are

\footnotetext{
${ }^{5}$ Some data was from 2011 and 2013

${ }^{6}$ The first two paragraphs of the historical descriptions of this section is the summary of interview with Willy Kuert <The Founding of ISO (page 15-21)> in ISO (1997) "Friendship among Equals" - Recollections from ISO's first fifty years. More detailed history can be found at the following site: http://www.iso.org/iso/home/about/the iso story.htm.
} 
allowed to attend meetings as observers. Subscriber members are countries that pay reduced membership fees for the same privileges as correspondent members. Table 1 in the Appendix lists current members of ISO.

The scope of ISO work extends over all fields except electrical and electronic standards, which are the responsibility of IEC. ISO addresses a wide variety of subjects ranging from screw threads to solar energy. As of December 2011, work in ISO was carried out through some 3,335 technical bodies: 224 Technical Committees (TCs), 513 Subcommittees (SCs), 2,516 Working Groups (WGs), and 82 Ad Hoc Study Groups published more than 19,000 ISO standards since its inception. In addition, 1,419 new work items were registered and 4,007 work items appear on the programs of work of the TCs in 2011. The list of ISO TCs is available in Annex 2.1.

Around $78 \%$ of ISO member bodies are governmental institutions or organizations incorporated by public law, and the remaining $22 \%$ are private sector standards organizations ${ }^{7}$. ANSI, the U.S.A. member body to ISO, is one of the private-sector member bodies. Under the ANSI-NIST MOU ${ }^{8}$, ANSI is the recognized U.S.A. member body to ISO, and, through the USNC, to IEC.

ISO Central Secretariat in Geneva, Switzerland coordinates ISO operations, administers voting and approval procedures, and publishes international standards. The operational costs of ISO itself are estimated at 140 million Swiss francs per year ${ }^{9}$. Around 37 million Swiss francs represent the operational cost of ISO Central Secretariat, financed by membership fees $(55 \%)$, publications, and other services $(45 \%)$.

\subsubsection{ISO Structure}

The General Assembly of ISO is the ultimate authority for its work and is hosted annually by a member country. Principal Officers include the President, Vice-President (policy), Vice President (technical management), Vice-President (finance), Treasurer, and Secretary General.

Key bodies of ISO include the Council and its three Policy Developing Committees (PDCs), Council Standing Committees, Ad Hoc Advisory Groups, and the Technical Management Board (TMB). TMB manages the overall technical work of standards development, and establishes and dissolves Technical Committees (TC). Central Secretariat provides support services related to membership, technical committees, marketing, training and similar offerings. Figure 1 presents the overall structure of ISO.

\footnotetext{
${ }^{7}$ ISO (2009), ISO members. The list of ISO members are in Annex 1, comparing with those of IEC.

${ }^{8}$ For the full ANSI-NIST MOU, see Annex 6.

${ }^{9}$ Approximately \$150M U.S. dollars
} 


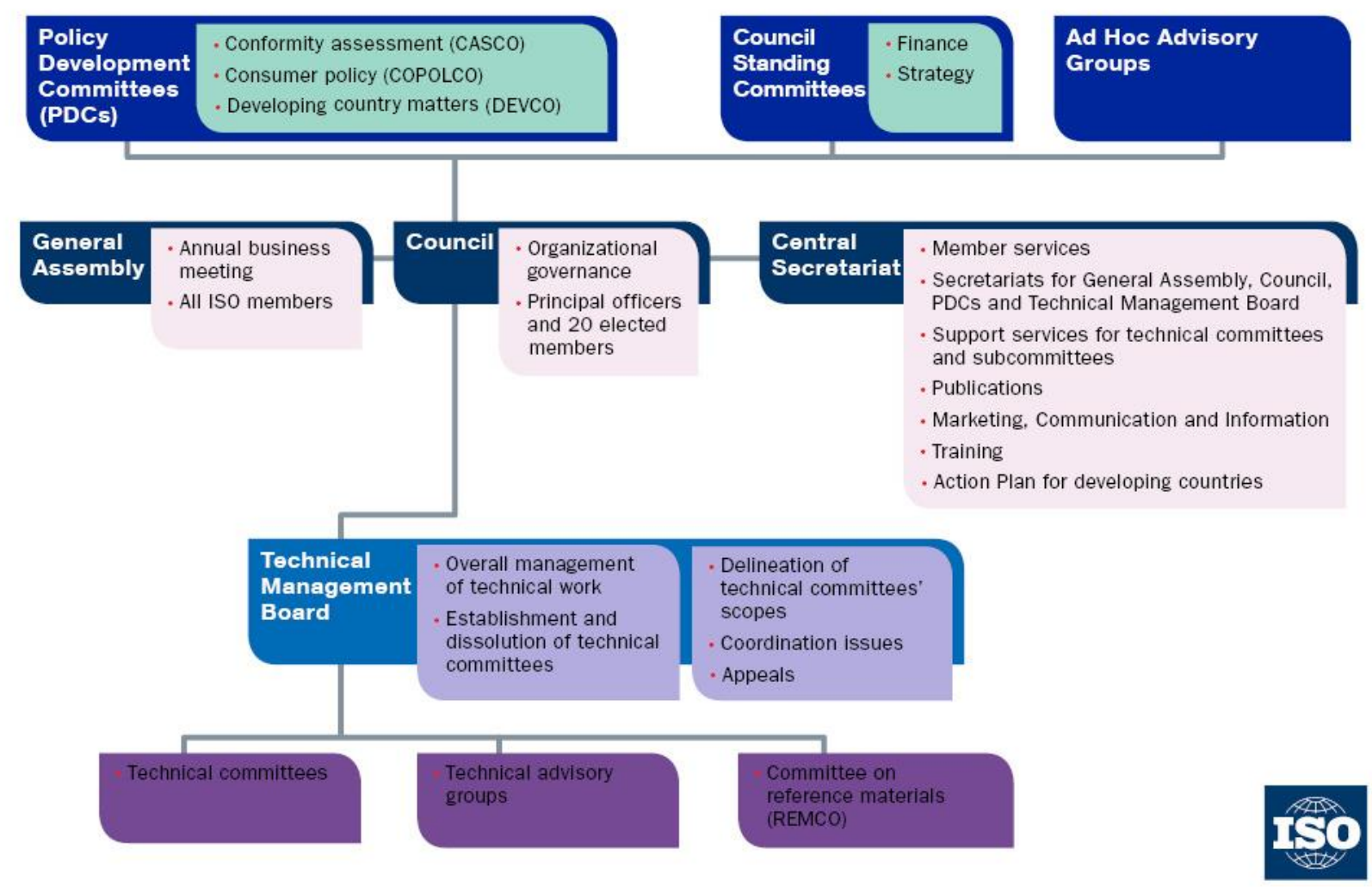

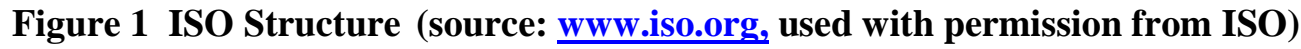

ISO members are categorized into three groups. Member bodies or full members participate in and influence ISO standards developing process; correspondence members attend and observe standards development; and subscriber members keep up to date on ISO's work. As of May 2014, ISO had 117 member bodies, 41 correspondent members, and four subscriber members. ${ }^{10}$ Among the total 162 member countries, only three countries are not also members of United Nations - Hong Kong, China; Macau, China; and Palestine. All of the 82 IEC members are also ISO members. The list of IEC members is available in Annex 1.

\subsection{U.S.A. Participation in ISO Technical Committees and Subcommittees}

Since the foundation of ISO in 1947, the U.S.A. has been a member body and Council Member. ISO Council takes care of most governance issues. The Council meets twice a year and is made up of 20 member bodies. Among them, only two countries, United Kingdom and France, have been Council Members of ISO since its foundation in 1947. In 2013, the member bodies elected to the Council are the following:

\footnotetext{
${ }^{10}$ For more information, see http://www.iso.org/iso/home/about/iso members.htm
} 
ABNT/Brazil (2013), AFNOR/France (2014), ANSI/U.S.A. (2014), BDS/Bulgaria (2013), BIS /India (2013), BSI/United Kingdom (2013), CYS/Cyprus (2013), DIN/Germany (2014), DSM/Malaysia (2014), EOS/Egypt (2013), ESMA/United Arab Emirates (2014), INNORPI/Tunisia (2014), IPQ/Portugal (2014), IRAM/Argentina (2014), JISC/Japan (2013), MCCAA/Malta (2014), NEN/Netherlands (2013), SA/Australia (2013), SAC/China (2013), and SIS/Sweden (2013).

Under the Council are a number of bodies that provide guidance and management on specific issues. U.S.A. participates in all of the committees under the council, including the three PDCs:

- CASCO - providing guidance on conformity assessments;

- $\mathrm{COPOLCO}$ - providing guidance on consumer issues, and

- $\mathrm{DEVCO}$ - providing guidance on matters related to developing countries.

U.S.A. also participates in the Council Standing Committees that advise on financial and strategic matters of ISO.

ISO's Annual Report 2011 indicates that ISO had 3,335 technical bodies, including 224 TCs, 513 SCs, 2516 WGs, and 82 Ad Hoc Study Groups ${ }^{11}$. ISO member bodies may register as participating (P-member), observer (O-member), or not represent at committee level based on their interests and resources. Pmembers have the right to vote while $\mathrm{O}$-members do not.

As shown in Table 2, by the end of 2012 the U.S.A. was participating in 620 (84\%) out of the total 737 ISO TCs and SCs, placing it $12^{\text {th }}$ in the ranks of committee participation. The U.S.A. had 583 P-members (171 TCs and 412 SCs), and 37 O-members (26 TCs and 11 SCs) of ISO. ${ }^{12}$ By comparison in 1998, the U.S.A. participated in $74 \%$ of TCs as a P-member, and $4 \%$ of TCs as an O-member. In 1986, the U.S.A. was designated an active participant in $69 \%$ of TCs, and an observer in $29 \%$ of TCs.

\footnotetext{
${ }^{11}$ ISO Annual Report 2011, or ISO in figures for the year 2011 (as of Dec 31, 2012, published on Feb 16, 2012)

${ }^{12}$ ISO website http://www.iso.org/iso/home/about/iso members.htm , accessed on Dec 31, 2012.
} 
Table 2 Top 20 Countries in ISO Participation (P- and O-members) (Dec 2012) ${ }^{13}$

\begin{tabular}{lllll}
\hline No. & Country & $\begin{array}{l}\text { Member } \\
\text { Body }\end{array}$ & $\begin{array}{l}\text { Membership } \\
\text { Status }\end{array}$ & $\begin{array}{l}\text { TC } \\
\text { participation }\end{array}$ \\
\hline 1 & United Kingdom & BSI & Member body & 726 \\
2 & France & AFNOR & Member body & 724 \\
3 & Germany & DIN & Member body & 718 \\
\hline 4 & Korea, Republic of & KATS & Member body & 711 \\
\hline 5 & China & SAC & Member body & 706 \\
\hline 6 & Japan & JISC & Member body & 687 \\
7 & Romania & ASRO & Member body & 687 \\
8 & Italy & UNI & Member body & 666 \\
\hline 9 & Poland & PKN & Member body & 643 \\
\hline 10 & Spain & AENOR & Member body & 625 \\
11 & Russian Federation & GOST R & Member body & 622 \\
\hline $\mathbf{1 2}$ & USA & ANSI & Member body & $\mathbf{6 2 0}$ \\
13 & India & BIS & Member body & 610 \\
\hline 14 & Netherlands & NEN & Member body & 596 \\
\hline 15 & Czech Republic & UNMZ & Member body & 595 \\
\hline 16 & Finland & SFS & Member body & 560 \\
\hline 17 & Belgium & NBN & Member body & 545 \\
\hline 18 & Switzerland & SNV & Member body & 540 \\
\hline 19 & Sweden & SIS & Member body & 536 \\
\hline 20 & Austria & ASI & Member body & 531 \\
\hline & & & & \\
\hline
\end{tabular}

${ }^{13}$ ISO website http://www.iso.org/iso/home/about/iso members.htm , accessed on Dec 31, 2012.

${ }^{14}$ ANSI is the only private-sector member body - the rest are governmental bodies. 


\subsection{U.S.A. Leadership in ISO TCs and SCs (Jan 2012)}

ISO's Annual Report 2011 indicates that the U.S.A. held 117 secretariats (see Annex 3.1) of the 737 ISO TCs and SCs, and 509 convenors of the 2,516 WGs. The U.S.A. held 616 positions (19.2\%) out of 3,253 leadership positions in ISO in January 2012.

In theory, a secretariat should act in a purely international capacity, divesting itself of a national point of view. In practice, it could be advantageous to hold a Secretariat, at a minimum ensuring that its national body is represented in international discussions.

Table 3 below demonstrates the progression in secretariats and convenors held by the United States in the years 1966, 1986, 1998, and 2012. By 1998, the U.S.A. held the secretariats for $31(16.8 \%)$ of the $184 \mathrm{TCs}, 110$ (18.7\%) of the $587 \mathrm{SCs}$, and 431 (21.3\%) of the 2,020 Working Groups. These figures include the ISO/IEC Joint Technical Committee (JTC 1). When added together, the United States held 572 (20.5\%) of the 2,791 leadership positions available in ISO. Between 1998 and 2012 the number of ISO secretariats and convenors held by the U.S.A. decreased slightly by a little more than $1 \%$, primarily due to a decrease in the number of secretariats.
ISO Secretariat Responsibilities

"The secretariat is responsible for monitoring, reporting, and ensuring active progress of the work, and shall use its utmost endeavor to bring this work to an early and satisfactory conclusion. These tasks shall be carried out as far as possible by correspondence. In all circumstances, the secretariat shall work in close liaison with its TC/SCs chair, WG convenors and project leaders. The secretariat is responsible for ensuring that ISO/IEC Directives and the decisions of the technical management board are followed."

From: ISO/IEC Directive, Part I 'Procedures for the technical work' (ninth edition, 2012)

Table 3 ISO Secretariats and Convenors over Time (1966-2012)

\begin{tabular}{llllll}
\hline Positions & & $\mathbf{1 9 6 6}^{\mathbf{1 5}}$ & $\mathbf{1 9 8 6}$ & $\mathbf{1 9 9 8}$ & $\mathbf{2 0 1 2}$ \\
\hline Secretariats & Total & 118 & 809 & 771 & 737 \\
& USA & 10 & 85 & 141 & 117 \\
& $\begin{array}{l}\text { U.S.A. ratio } \\
\text { (\%) }\end{array}$ & $8.5 \%$ & $10.5 \%$ & $18.3 \%$ & $15.9 \%$ \\
& Total & $\mathrm{n} / \mathrm{a}$ & 1556 & 2020 & 2516 \\
& USA & $\mathrm{n} / \mathrm{a}$ & 212 & 431 & 509 \\
& U.S.A. ratio & $n / a$ & $13.6 \%$ & $21.3 \%$ & $20.2 \%$ \\
& (\%) & & & & \\
& Total & 118 & 2365 & 2791 & 3253 \\
& USA & 10 & 297 & 572 & 626 \\
& U.S.A. ratio & $8.5 \%$ & $12.6 \%$ & $20.5 \%$ & $19.2 \%$ \\
\hline
\end{tabular}

Table 4 lists the top 20 countries in terms of the secretariats and convenors in ISO TC/SCs in ISO, where U.S.A. ranks the $2^{\text {nd }}$ in secretariats and the $1^{\text {st }}$ in convenors.

\footnotetext{
${ }^{15}$ For the year of 1966 , the total number of committees does not include SC, but TC only.
} 
Table 4 Top 20 Countries Holding ISO Secretariat and Convenor Roles in 2011

\begin{tabular}{llllllll}
\hline No. & Country (MB) & Secr. & Ratio & No. & Country (MB) & Conv. & Ratio \\
\hline $\mathbf{1}$ & Germany (DIN) & 130 & $17.6 \%$ & $\mathbf{1}$ & U.S.A. (ANSI) & $\mathbf{5 0 9}$ & $\mathbf{2 0 . 2} \%$ \\
$\mathbf{2}$ & U.S.A. (ANSI) & $\mathbf{1 1 7}$ & $\mathbf{1 5 . 9} \%$ & 2 & United Kingdom (BSI) & 355 & $14.1 \%$ \\
$\mathbf{3}$ & United Kingdom (BSI) & 70 & $9.5 \%$ & 3 & Germany (DIN) & 352 & $14.0 \%$ \\
$\mathbf{4}$ & France (AFNOR) & 69 & $9.4 \%$ & 4 & France (AFNOR) & 212 & $8.4 \%$ \\
$\mathbf{5}$ & Japan (JISC) & 67 & $9.1 \%$ & 5 & Japan (JISC) & 193 & $7.7 \%$ \\
$\mathbf{6}$ & China (SAC) & 45 & $6.1 \%$ & 6 & Sweden (SIS) & 88 & $3.5 \%$ \\
$\mathbf{7}$ & Sweden (SIS) & 25 & $3.4 \%$ & 7 & Canada (SCC) & 80 & $3.2 \%$ \\
$\mathbf{8}$ & Australia (SA) & 19 & $2.6 \%$ & 8 & Netherlands (NEN) & 78 & $3.1 \%$ \\
$\mathbf{9}$ & Netherlands (NEN) & 19 & $2.6 \%$ & 9 & Australia (SA) & 76 & $3.0 \%$ \\
$\mathbf{1 0}$ & Switzerland (SNV) & 18 & $2.4 \%$ & 10 & Korea, Rep. of (KATS) & 65 & $2.6 \%$ \\
$\mathbf{1 1}$ & Canada (SCC) & 17 & $2.3 \%$ & 11 & China (SAC) & 60 & $2.4 \%$ \\
$\mathbf{1 2}$ & Italy (UNI) & 16 & $2.2 \%$ & 12 & Italy (UNI) & 42 & $1.7 \%$ \\
$\mathbf{1 3}$ & Korea, Rep. of (KATS) & 16 & $2.2 \%$ & 13 & Belgium (NBN) & 34 & $1.4 \%$ \\
$\mathbf{1 4}$ & Norway (SN) & 11 & $1.5 \%$ & 14 & Switzerland (SNV) & 34 & $1.4 \%$ \\
$\mathbf{1 5}$ & Russian Fed. (GOST R) & 9 & $1.2 \%$ & 15 & Norway (SN) & 33 & $1.3 \%$ \\
$\mathbf{1 6}$ & South Africa (SABS) & 9 & $1.2 \%$ & 16 & Denmark (DS) & 26 & $1.0 \%$ \\
$\mathbf{1 7}$ & Brazil (ABNT) & 8 & $1.1 \%$ & 17 & Brazil (ABNT) & 21 & $0.8 \%$ \\
$\mathbf{1 8}$ & India (BIS) & 8 & $1.1 \%$ & 18 & Spain (AENOR) & 18 & $0.7 \%$ \\
$\mathbf{1 9}$ & Denmark (DS) & 7 & $0.9 \%$ & 19 & Austria (ASI) & 16 & $0.6 \%$ \\
$\mathbf{2 0}$ & Spain (AENOR) & 7 & $0.9 \%$ & 20 & Finland (SFS) & 16 & $0.6 \%$ \\
$\mathbf{-}$ & Remaining Countries & 50 & $6.8 \%$ & - & Remaining Countries & 208 & $8.3 \%$ \\
$\mathbf{-}$ & Secretariat Total & $\mathbf{7 3 7}$ & $\mathbf{1 0 0 . 0} \%$ & - & Convenor Total & $\mathbf{2 , 5 1 6}$ & $\mathbf{1 0 0 . 0 \%}$ \\
\hline
\end{tabular}

\section{U.S.A. Participation in IEC}

\subsection{About IEC}

\subsubsection{IEC Activities Since 190616}

IEC is a not-for-profit, non-governmental organization, founded in 1906. In the late $19^{\text {th }}$ century the lack of standardization of electrical equipment had become a worldwide problem, even though the importance of electrical measuring units had been universally recognized. With the development of economic generators,

${ }^{16}$ This section is based on the IEC history section of the website: http://www.iec.ch/about/history/overview/ 
filament lamps, fittings, and reliable cables, local authorities and distributors for the first time could choose between the merits of different designs. While the series of International Electrical Congresses, particularly those between 1881 and 1900, had been solely concerned with electric units and standards, it was at the 1904 St. Louis, USA, Congress that, in the interests of commercial transactions and trade, the proposal was made for establishing a permanent international commission to study the unification of electrical machines and apparatuses.

IEC is financed by a combination of membership dues and revenues from the sales of its publications. IEC's 2010 Annual Report indicates that the total membership dues amounted to US\$11.65 million while revenues from sales (both direct sales and royalties) came to US\$9.54 million, which along with other revenues resulted in a total net income of US\$24 million.

IEC Central Office in Geneva, Switzerland coordinates IEC operations, administers voting and approval procedures, and publishes international standards. Similar to ISO, IEC NCs that participate in a TC or a SC are P-members, and NCs that want to be kept informed of ongoing work are O-members.

\subsubsection{IEC Structure}

The objective of IEC is to promote international cooperation on all questions of standardization in the fields of electrical and electronic engineering. IEC's members are National Committees (NC), and they appoint experts and delegates from industry, government bodies, associations, and academia to participate in the technical and conformity assessment work of IEC. Each NC is required to be as representative as possible of all electrical-related interests in its country including manufacturers, users, governmental authorities, and educational and professional bodies. Many NCs receive a large amount of support from industry; many are recognized and financially supported by their governments.

The work of IEC is currently carried out by 97 TCs and 111 SCs, and close to 1,200 working-level groups. The committees span a wide range of electrotechnical sectors and have developed 6,959 standards related documents, including 6,271 standards, 226 technical specifications, 407 technical reports, and 55 IEC Publically Available Specifications (IEC-PAS), and had 1,489 active projects as of December $2012^{17}$. The list of IEC TCs is provided in Annex 2.2.

The Council of IEC is a legislative body and is the supreme governing body of IEC. Its members include the Presidents of all IEC Full Member NCs, the current IEC Officers and all Past Presidents, and the Council Board members. The Council sets IEC policy and long-term strategic and financial objectives. It delegates the management of IEC work to the CB (Council Board), with specific management responsibilities in the spheres of standards, conformity assessment, and market strategy being assumed, respectively by the Standardization Management Board (SMB), the Market Strategy Board (MSB), and the Conformity Assessment Board (CAB). The structure of IEC is shown in Figure 2.

\footnotetext{
${ }^{17}$ Updates may be found at http://www.iec.ch/dyn/www/f?p=103:6:0\#\#ref=menu
} 


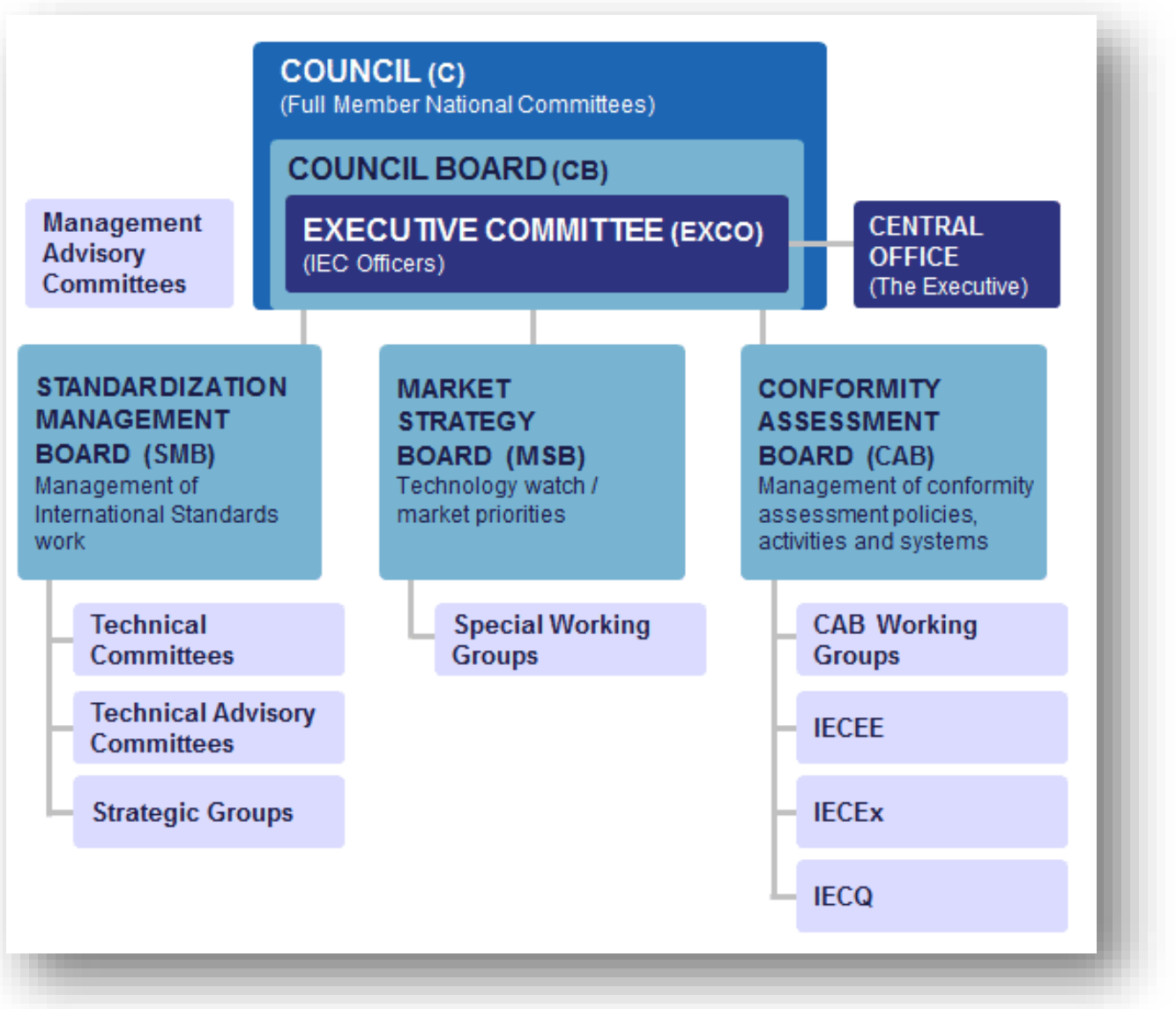

Figure 2 IEC Structure (source: $\underline{\text { www.iec.ch, }}$ used with permission of IEC)

IEC Council delegates the management and supervision of IEC's standards work to the SMB. The SMB is a decision-making body that reports to the CB. The SMB is responsible for setting-up and disbanding TCs and SCs, approving their scopes, appointing TC/SC chairmen and allocating secretariats, allocating standards work, timeliness of standards production, and approval and maintenance of the Directives, reviewing the need for and planning for IEC work in new fields of technology, and maintaining liaisons with other international organizations.

The MSB reports to the CB and identifies the principal technological trends and market needs in IEC's fields of activity.

The CAB is responsible for setting IEC's conformity assessment policy, promoting and maintaining relations with international organizations on conformity assessment matters, creating, modifying and disbanding conformity assessment systems, monitoring the operation of conformity assessment activities, and examining the continued relevance of IEC's conformity assessment activities in general. 


\subsubsection{ISO and IEC: Relationships including Joint Technical Committee (JTC) $1^{18}$}

ISO and IEC have a formal agreement in place that establishes a non-duplicative and cooperative relationship between the two organizations. In accordance with this agreement, the two organizations complement each other in the field of international standardization. IEC is responsible for issues relating to international standardization in the electrical and electronic engineering fields, while other areas are the responsibilities of ISO. In areas that do not relate to a particular technology, ISO assumes responsibility for the work and ensures that any electrotechnical issues that arise are addressed in consultation with IEC.

The standards development processes of ISO and IEC are described in Annex 4.

\subsection{U.S.A. an IEC Member Since Its Foundation in $1906^{19}$}

Since IEC's foundation in 1906 in London, the U.S.A. has been an active member, participating in and leading IEC's standardization and conformity assessment activities. IEC Council Board includes the U.S.A. and 14 other national committees from Australia, Austria, Brazil, Canada, China, France, Germany, Italy, Japan, Korea, Netherlands, South Africa, Sweden, and United Kingdom. The U.S.A. or its individual experts have been vigorously involved in all of the major committees and groups of IEC including IEC SMB and IEC CAB.

The U.S.A. National Committee (USNC) of IEC manages U.S.A. participation in the technical work of IEC. ANSI provides secretariat services to the USNC, its executive committee, technical advisors, and technical advisory groups. It takes part in the Commission's entire technical program and holds secretariats of approximately 24 TCs and SCs. Among them are committees that develop international standards in the areas of semiconductor devices, household appliances, air-conditioning appliances, laser equipment, solar photovoltaic energy systems, fiber optics systems, design automation, and electrical insulation systems, among others.

The USNC appoints a technical advisor (TA) and a technical advisory group (TAG) to develop the U.S.A. position for each TC and SC. TAs and TC and SC delegates are drawn from U.S.A. professional societies, trade associations, companies, government agencies, testing laboratories, and other interested stakeholders concerned with the development of national electro-technical standards. The TA develops the U.S.A. position on IEC committee matters by consulting with the TAG. The TA is also responsible for ensuring that the U.S.A. position is presented to the appropriate IEC TC.

\footnotetext{
${ }^{18}$ This section is fully based on the previous 2000 NIST report (NISTIR 6942)

${ }^{19}$ More information about U.S. participation history in IEC can be found at http://www.ansi.org/standards activities/iec programs/governance committees/history.aspx?menuid=3\#.UQG85h1QXeB
} 


\subsubsection{ISO/IEC JTC $1^{20}$}

ISO and IEC started work on information technology (IT) standardization around 1960 during the initial stages of computerization. As the industry took off with rapid innovation and widespread acceptance, both ISO and IEC worked to keep pace with the development of responsive standards. In the 1980s, IT technological innovations became more complex and far-reaching; the international standardization community recognized that a comprehensive venue in which to address all aspects of information and communication technology (ICT) standardization was needed; therefore, in 1987, JTC 1 was formed by the merger of ISO TC 97 (Information technology) and IEC TCs 47B (Microprocessor systems) and 83 (Information technology equipment). Bringing together the qualities and strengths of ISO and IEC, JTC 1 was positioned to speed progress and wide deployment and avoid the development of duplicative or possibly incompatible standards by the two organizations.

The JTC 1 is recognized as one of the largest and most prolific technical committees in the international standardization community. Its 19 active subcommittees ${ }^{21}$ have produced over 2,600 published standards and continue to make tremendous impacts on the ICT industry worldwide.

The U.S.A. has played a leadership role in the work of JTC 1, with ANSI serving as secretariat. JTC 1 counts 37 countries among its participants (plus another 54 as observers), and over 2,000 experts from around the world represent their national body positions in collaboration to develop the most effective and relevant ICT standards. It is the efforts of these dedicated professionals that drive JTC 1's record of accomplishment.

This approach has enabled JTC 1 to make great progress in developing standards that cross a broad swath of technology sectors, particularly in rapidly expanding IT-related areas such as cloud computing, security, sustainability, and accessibility. JTC 1 is currently addressing such critical areas as teleconferences and emeetings, cloud data management interface, biometrics in identity management, sensor networks for smart grid systems, and corporate governance of IT implementation.

\subsection{U.S.A. Participation in IEC SCs and TCs (April 2013)}

IEC has 172 committees consisting of 95 TCs and 77 SCs of which 187 are IEC-only committees and 21 are ISO/IEC joint committees. Table 5 presents the 185 IEC-only committees, including 89 SCs with advisory or special committees as well as 96 TCs. These 185 committees contain 1,191 working-level groups: 437 working groups, 239 project teams, and 515 maintenance teams ${ }^{22}$.

\footnotetext{
${ }^{20}$ This section is largely based on the ASNI's press release in JTC 1's 25 year celebration, released on June 28, 2012, available at http://www.ansi.org/news_publications/print_article.aspx?articleid=3270, and ISO's website

${ }^{21}$ The list of JTC 1 subcommittees is in Annex 2.3.

${ }^{22}$ Source: http://www.iec.ch/members experts/refdocs/facts.htm (accessed on Dec 31, 2012)
} 
Table 5 Number of IEC TCs and SCs as of April 2013 (source: www.iec.ch)

\begin{tabular}{lllll}
\hline Class & Descriptions & Number of TCs & Number of SCs & Total \\
\hline TCs and SCs & & 95 & 77 & 172 \\
TAs & TC100/TAs & 0 & 12 & 12 \\
PCs & PC 118 & 1 & 0 & 1 \\
Total & & $\mathbf{9 6}$ & $\mathbf{8 9}$ & $\mathbf{1 8 5}$ \\
\hline
\end{tabular}

Among the 187 IEC committees, the U.S.A. is a participating member (P-member) in 162 committees $(86.6 \%), 89 \mathrm{TCs}(93.7 \%)$ and $73 \mathrm{SCs}(79.3 \%)$. This figure includes the CAB document voting. The U.S.A. does not participate as an observer member in any IEC committees. The U.S.A. is ranked $7^{\text {th }}$ in the number of P-members in IEC committees. Table 6 lists the top 20 countries sorted by the number of Pmembers in IEC committees. In 1998, the U.S.A. had 77 (74.4 \%) P-members and no O-members out of $184 \mathrm{TCs} / \mathrm{SCs}$; in 1986, there were 140 (68.9\%) P-members and 50 (24.6\%) O-members out of 203 TCs/SCs.

Table 6 Top 20 Countries in IEC P-memberships (Dec 2012)

\begin{tabular}{lllllll}
\hline Rank & Country & NC & Membership & P-Member & O-Member & P+O \\
\hline $\mathbf{1}$ & China & SAC & Full Member & 177 & 0 & 177 \\
$\mathbf{2}$ & Germany & DKE & Full Member & 177 & 0 & 177 \\
$\mathbf{3}$ & Japan & JISC & Full Member & 174 & 2 & 176 \\
$\mathbf{4}$ & United Kingdom & BSI & Full Member & 170 & 5 & 175 \\
$\mathbf{5}$ & Italy & CEI & Full Member & 166 & 11 & 177 \\
$\mathbf{6}$ & France & UTE & Full Member & 165 & 12 & 177 \\
$\mathbf{7}$ & USA & ANSI & Full Member & $\mathbf{1 6 2}$ & $\mathbf{0}$ & $\mathbf{1 6 2}$ \\
$\mathbf{8}$ & Russian Federation & GOST R & Full Member & 152 & 16 & 168 \\
$\mathbf{9}$ & Korea, Republic of & KATS & Full Member & 143 & 31 & 174 \\
$\mathbf{1 0}$ & Finland & SESKO & Full Member & 141 & 32 & 173 \\
$\mathbf{1 1}$ & Spain & AENOR & Full Member & 136 & 40 & 176 \\
$\mathbf{1 2}$ & Sweden & SEK & Full Member & 135 & 41 & 176 \\
$\mathbf{1 3}$ & Netherlands & NEN & Full Member & 126 & 33 & 159 \\
$\mathbf{1 4}$ & Switzerland & CES & Full Member & 125 & 22 & 147 \\
$\mathbf{1 5}$ & Denmark & DS & Full Member & 118 & 55 & 173 \\
$\mathbf{1 6}$ & Austria & OVE & Full Member & 115 & 50 & 165 \\
$\mathbf{1 7}$ & Belgium & BEC & Full Member & 105 & 63 & 168 \\
$\mathbf{1 8}$ & Romania & ASRO & Full Member & 93 & 69 & 162 \\
\hline & & & & & \\
\hline
\end{tabular}




\begin{tabular}{lllllll}
\hline $\mathbf{1 9}$ & Canada & SCC & Full Member & 91 & 24 & 115 \\
$\mathbf{2 0}$ & Australia & SA & Full Member & 90 & 49 & 139 \\
\hline
\end{tabular}

\subsection{U.S.A. Leadership in IEC TCs and SCs (December 2012)}

The U.S.A. held 24 TC/SC secretariats $(12.8 \%)^{23}$ ranking $4^{\text {th }}$ behind Germany, France, and Japan (see Annex 3.2) and 31 Chairs $(16.6 \%)^{24}$ ranking $2^{\text {nd }}$ behind Germany as summarized in Table 7. IEC does not provide statistics for convenors.

Table 7 Top 15 Countries in IEC Secretariats and Chairs in September 2012

\begin{tabular}{|c|c|c|c|c|c|c|c|}
\hline & Secretariats & & & & Chairs & & \\
\hline No. & Country & Sec. & Ratio & No. & Country & Chair & Ratio \\
\hline 1 & Germany & 34 & $18.2 \%$ & 1 & Germany & 37 & $19.8 \%$ \\
\hline 2 & France & 24 & $12.8 \%$ & 2 & USA & 31 & $16.6 \%$ \\
\hline 3 & Japan & 24 & $12.8 \%$ & 3 & United Kingdom & 22 & $11.8 \%$ \\
\hline 4 & $\boldsymbol{U S A}$ & 24 & $12.8 \%$ & 4 & France & 18 & $9.6 \%$ \\
\hline 5 & United Kingdom & 20 & $10.7 \%$ & 5 & Italy & 13 & $7.0 \%$ \\
\hline 6 & Italy & 13 & $7.0 \%$ & 6 & Japan & 9 & $4.8 \%$ \\
\hline 7 & China & 6 & $3.2 \%$ & 7 & Sweden & 6 & $3.2 \%$ \\
\hline 8 & Sweden & 6 & $3.2 \%$ & 8 & Canada & 5 & $2.7 \%$ \\
\hline 9 & Korea, Republic of & 5 & $2.7 \%$ & 9 & Finland & 5 & $2.7 \%$ \\
\hline 10 & Spain & 5 & $2.7 \%$ & 10 & China & 4 & $2.1 \%$ \\
\hline 11 & Canada & 3 & $1.6 \%$ & 11 & Denmark & 3 & $1.6 \%$ \\
\hline 12 & Netherlands & 3 & $1.6 \%$ & 12 & Netherlands & 3 & $1.6 \%$ \\
\hline 13 & Switzerland & 3 & $1.6 \%$ & 13 & Australia & 2 & $1.1 \%$ \\
\hline 14 & Australia & 2 & $1.1 \%$ & 14 & Norway & 2 & $1.1 \%$ \\
\hline 15 & $\begin{array}{l}\text { Belgium, Norway, } \\
\text { Russian Federation, } \\
\text { South Africa } \\
\text { ( } 4 \text { countries) }\end{array}$ & $\begin{array}{l}2 \\
(8)\end{array}$ & $\begin{array}{l}1.1 \% \\
(4.3 \%)\end{array}$ & 15 & $\begin{array}{l}\text { Austria, Belgium, Brazil } \\
\text { Switzerland, Spain } \\
\text { Ireland, Israel, Korea } \\
\text { New Zealand, Poland } \\
\text { South Africa (11 countries) }\end{array}$ & $\begin{array}{l}1 \\
(11)\end{array}$ & $\begin{array}{l}0.5 \% \\
(5.9 \%)\end{array}$ \\
\hline- & Remaining Countries & 7 & $3.7 \%$ & - & Remaining Countries & 16 & $8.3 \%$ \\
\hline- & Secretariat Total & 187 & $100.0 \%$ & - & Chair Total & 187 & $100.0 \%$ \\
\hline
\end{tabular}

\footnotetext{
${ }^{23}$ IEC website as accessed on Dec. 31, 2012.

${ }^{24}$ The 2012 IEC Activity Report to IEC Council by General Secretary on Oct. 5, 2012 in Oslo, Norway.
} 
Table 8 depicts the percentage of total IEC TC and SC Secretariats held by the U.S.A. from previous years, which increased from $8.5 \%$ in 1966 to $16.8 \%$ in 1998 , but then slightly decreased to $12.8 \%$ in 2011 .

Table 8 IEC Change in Secretariats Held 1966 to $2012^{25}$

\begin{tabular}{llllll}
\hline Positions & & $\mathbf{1 9 6 6}^{\mathbf{2 6}}$ & $\mathbf{1 9 8 6}$ & $\mathbf{1 9 9 8}$ & $\mathbf{2 0 1 2}$ \\
\hline Secretariats & Total & 153 & 203 & 184 & 187 \\
& USA & 12 & 33 & 31 & 24 \\
& $\begin{array}{l}\text { U.S.A. Ratio } \\
\text { (\%) }\end{array}$ & $8.5 \%$ & $16.3 \%$ & $16.8 \%$ & $12.8 \%$ \\
& U.S.A. Rank & $4^{\text {th }}$ & $2^{\text {nd }}$ & $1^{\text {st }}$ & $4^{\text {th }}$ \\
\hline
\end{tabular}

\subsection{U.S.A. Number of Experts and New Proposals in 2012}

IEC 2012 Activity Report presents two additional important figures: the number of experts who participated in IEC work and the number of new proposals by country. ${ }^{27}$ IEC created an Expert Management System in 2004 to track a participant's degree of participation as an Expert and their authorization to access the relevant documentation. The System provides the number of participating experts in IEC work since 2005. As displayed in Table 9, 1,646 U.S.A. experts participated in IEC work in 2012, and the U.S.A. ranked $2^{\text {nd }}$ following Germany. In 2005, the U.S.A. ranked $1^{\text {st }}$ with 1,090 experts who participated in IEC.

IEC also provides the number of new proposals for standards by the Secretariat and the national committees. 'New proposals for standards' are interpreted as being in the 'proposal stage,' and are not yet accepted as new projects or final standards. In 2012, around $30 \%$ of the new proposals came from secretariats and $70 \%$ from national committees. In 2012 the U.S.A. submitted 17 new proposals, ranking $4^{\text {th }}$ among all members, and in 1999, ranked $3^{\text {rd }}$ with 13 new project proposals as shown in Table 10.

Table 9 Top 10 Countries in IEC Participation of Experts $(2005,2012)$

\begin{tabular}{llllll}
\hline $\mathbf{2 0 0 5}$ & & \multicolumn{5}{c}{2012} & Experts \\
\hline Rank & Country & Experts & Rank & Country & 1,819 \\
$\boldsymbol{I}$ & USA & 1,090 & 1 & Germany & $\mathbf{1 , 6 4 6}$ \\
2 & Germany & 1,067 & $\mathbf{2}$ & $\boldsymbol{U S A}$ & \\
\hline
\end{tabular}

\footnotetext{
${ }^{25}$ The data for Chairs is not available in the two previous NIST reports. Currently available data for IEC chairs is IEC General Secretary activity reports announced during the years of 2005 to 2012.

${ }^{26}$ For 1966, the total number of committees includes technical committees only, excluding subcommittees.

${ }^{27}$ Some of the early-year IEC activity reports were kindly provided by (Mr.) Jack Sheldon, Standardization Strategy Manager at IEC Central Office.
} 


\begin{tabular}{llllll}
\hline 3 & Japan & 819 & 3 & Japan & 1,524 \\
4 & UK & 716 & 4 & UK & 805 \\
5 & France & 577 & 5 & China & 781 \\
6 & Italy & 383 & 6 & France & 720 \\
7 & Sweden & 257 & 7 & Korea, Republic of & 623 \\
8 & Canada & 247 & 8 & Sweden & 476 \\
9 & Netherlands & 188 & 9 & Italy & 468 \\
10 & Korea, Republic of & 184 & 10 & Switzerland & 337 \\
\hline
\end{tabular}

Table 10 Source of IEC New Proposals $(1999,2012)^{28}$

\begin{tabular}{llllll}
\hline $\mathbf{1 9 9 9}$ & & \multicolumn{2}{c}{$\mathbf{2 0 1 2}$} & \\
\hline Rank & Country & NPs & Rank & Country & NPs \\
\hline- & Secretariat & 70 & - & Secretariat & 58 \\
1 & Japan & 16 & 1 & Japan & 22 \\
2 & Germany & 14 & 2 & Germany & 21 \\
$\mathbf{3}$ & USA & $\mathbf{1 3}$ & 3 & Korea, Rep of & 20 \\
4 & UK & 8 & $\mathbf{4}$ & $\boldsymbol{U S A}$ & $\mathbf{1 7}$ \\
5 & Netherlands & 7 & 5 & China & 15 \\
6 & France & 4 & 6 & France & 10 \\
7 & Italy & 2 & 7 & Switzerland & 8 \\
8 & Sweden & 2 & 8 & Netherlands & 5 \\
$9-12$ & Austria, Poland, Spain, Switzerland & 1 & $9-10$ & Denmark, Italy & 3 \\
\hline
\end{tabular}

\section{Agreement-Based Participation by U.S.A.-Domiciled SDOs or Consortia}

There are other levels of participation by U.S.A.-domiciled standards-developing organizations and consortia in ISO and IEC standardization activities. This section presents some examples of such because there is no comprehensive survey available in this regard.

\subsection{IEEE's Partnerships with ISO and IEC ${ }^{29}$}

The Institute of Electrical and Electronics Engineers, Inc. (IEEE) is the world's largest technical professional society. Through its more than 370,000 members in 160 countries, the organization focuses on

\footnotetext{
${ }^{28}$ Source: 1999 and 2012 IEC Activity Report by General Secretary, which represents the activities in Oct 1998 to September 1999 and October 2011 to September 2012 respectively. The ranking and the number of new proposals by countries is transformed from the visual chart in that report by authors and may include read-error.

${ }^{29}$ IEEE provides detailed information about the organization's level of collaboration with ISO and IEC. More information about IEEE's partnership with ISO and IEC is available at: http://standards.ieee.org/develop/intl/index.html.
} 
a wide variety of areas ranging from aerospace systems, computers, and telecommunications to biomedical engineering, electric power, and consumer electronics, and has developed nearly 900 active industry standards.

\subsubsection{ISO/IEEE PSDO Agreement Since 2008}

ISO and IEEE have a Partner Standards Development Organization (PSDO) cooperation agreement in place to increase their cooperation in developing international standards. The PSDO cooperation agreement provides new opportunities to adopt and jointly develop international standards to serve the global marketplace. The agreement aims to optimize stakeholder resources in the development of standards where both ISO and IEEE have expertise, and to shorten time-to-market. The agreement facilitates processes for the joint development of standards and for the adoption of standards. The agreement currently focuses on the following three TCs and six SCs of ISO:

- ISO/TC 204 - Intelligent Transportation Systems

- ISO/TC 215 - Health Informatics

- ISO/IEC JTC 1

- SC6 - Telecommunications and Information Exchange Between Systems

- SC7 - Software and System Engineering

- SC22 - Programming Languages, their Environments and System Software Interfaces

- SC25 - Interconnection of Information Technologies

- SC31 - Automatic Identification and Data Capture Techniques

- SC36 - Information Technology for Learning, Education, and Training (ITLET)

IEEE documents 51 standards adopted or jointly developed as of December 2012 under the ISO/IEEE PSDO Agreement. These include standards for Health Informatics (12), Instrumentation and Measurement (4), Local and Metropolitan Networks (10), Microprocessors (6), Portable Operating System Interface (POSIX) (7), and Software and System Engineering (12). ${ }^{30}$

\subsubsection{IEC/IEEE Dual Logo Agreement Since 2002}

The IEC/IEEE Dual Logo Agreement originally aimed at identifying suitable IEEE standards and draft standards as candidates for processing through the IEC full-consensus procedure at the country level. The Agreement has been expanded to include the joint development of new or existing standards in parallel in both organizations. The Agreement involves a dual-logo arrangement in which the logos of both organizations will appear on documents adopted by and jointly developed with IEC.

IEEE documents 23 standards adopted or jointly developed as of December 2012 under the IEC/IEEE Dual Logo Agreement. These are in the areas of Design Automation (6), Dielectrics and Electrical Insulation (1), Instrumentation and Measurement (3), Nanotechnology (1), Nuclear Power Engineering (3), SCC20 - Test

${ }^{30}$ Additional information can be found at http://standards.ieee.org/develop/intl/dual.html 
and Diagnosis for Electronic Systems (2), Switchgear (1), Test Technology (4), and Transformers (2). ${ }^{31}$

\subsection{ASTM International's Partnerships with ISO Since 1999}

ASTM International, formerly known as the American Society for Testing and Materials (ASTM), develops globally recognized international voluntary consensus standards. Today, some 12,000 ASTM standards are used around the world to improve product quality, enhance safety, facilitate market access and trade, and build consumer confidence.

There have been two separate formal partnership activities between ASTM International and ISO. The first partnership ran from 1999 to 2004 for dosimetry standards development, and the second began in 2011 for additive manufacturing standards development.

From 1999 to 2004, ISO and ASTM International conducted a pilot project, "Radiation Processing Dosimetry Standards," which successfully transformed 25 ASTM dosimetry standards ${ }^{32}$ into ISO/ASTM standards. Implemented in 2001, detailed procedures enabled the ISO/ASTM standards to be reviewed and maintained by ASTM International with unrestricted participation and input from ISO. As part of the process, the revised standards were balloted independently by ISO and by ASTM International using their normal ballot procedures. These 25 standards included ISO/ASTM 51607-4 and ISO/ASTM 52116-02. Since the pilot program, all of the published standards have proceeded through the full maintenance cycle ${ }^{33}$.

In 2011, ISO and ASTM International signed an agreement to increase their cooperation in the development of international standards for additive manufacturing ${ }^{34}$ which refers to the process of joining materials to manufactured objects, usually layer upon layer, as opposed to "subtractive manufacturing" methods, such as machining. The Partner Standards Development Organization (PSDO) cooperation agreement provides new opportunities for the two organizations to adopt and jointly develop international standards that serve the global marketplace in the field of additive manufacturing. The decision to set up the PSDO agreement follows the recent creation of ISO/TC 261, Additive manufacturing. ASTM's committee F42, Additive Manufacturing Technology, had already initiated important work in this area and it was decided that both groups would benefit from combining their expertise. So far, three standards have been drafted for ballot under this PSDO agreement: ISO/ASTM DIS 52792, ISO/ASTM FDIS 52915, and ISO/ASTM 52921.

\footnotetext{
${ }^{31}$ More information can be found at http://standards.ieee.org/develop/intl/joint.html

${ }^{32}$ For full list please see http://www.astm.org/DATABASE.CART/I.htm, and scroll down to ISO/ASTM listings. Also, the subcommittee-based list can be found at http://www.astm.org/COMMIT/SUBCOMMIT/E61.htm, standards under the jurisdiction of E.61.01-E.61.05.

${ }^{33}$ Grove, Jeff (July/August 2011) "Promoting Public-Private Collaboration in Standards Development - Recommendations for an Enhanced Government-SDO Partnership in the United States, ASTM Standardization News (available at http://www.astm.org/SNEWS/JA_2011/grove_ja11.html).

${ }^{34}$ More information can be found at http://www.iso.org/iso/home/news index/news archive/news.htm?refid=Ref1481
} 


\subsection{Approved PAS Submitters to JTC 1, Including Some US-Domiciled Consortia ${ }^{35}$}

ISO and IEC publish different types of documents - international standards (IS), technical specifications (TS), technical reports (TR), guides, and publically available specifications (PAS) to achieve an optimum degree of order in a given context of standards development procedures and to describe where the document is used. PAS is a document published by ISO or IEC to respond to an urgent market need, representing either a) a consensus in an organization external to ISO or IEC, or b) a consensus of the experts within a working group ${ }^{36}$.

JTC 1 has a transposition procedure whereby organizations accredited as valid PAS Submitters can send their specifications directly for country voting to become ISO/IEC standards ${ }^{37}$. There are now nine approved PAS Submitters as of Jan $2013^{38}$ as Table 11 shows. The majority of them are US-domiciled or USoriginated standards development organizations, and 115 PASs have been approved so far through this PAS Submitter procedure for JTC $1^{39}$.

Table 11 List of Approved PAS Submitters to JTC 1

\begin{tabular}{|c|c|c|}
\hline No. & Organizations & Status \\
\hline 1 & $\begin{array}{l}\text { Advancing Storage and Information Technology (SNIA) } \\
\text { http://www.snia.org/ }\end{array}$ & $\begin{array}{l}\text { Approved status through } \\
\text { September } 2018\end{array}$ \\
\hline 2 & $\begin{array}{l}\text { Distributed Management Task Force, Inc. (DMTF) } \\
\text { http://www.dmtf.org/ }\end{array}$ & $\begin{array}{l}\text { Approved status through } \\
\text { January } 2019\end{array}$ \\
\hline 3 & $\begin{array}{l}\text { GS1 } \\
\text { http://www.gs1.org/ }\end{array}$ & $\begin{array}{l}\text { Approved status through } \\
\text { January } 2016\end{array}$ \\
\hline 4 & $\begin{array}{l}\text { Object Management Group (OMG) } \\
\text { http://www.omg.org/ }\end{array}$ & $\begin{array}{l}\text { Reaffirmed through } \\
\text { December } 2014\end{array}$ \\
\hline 5 & $\begin{array}{l}\text { Open Geospatial Consortium (OGC) } \\
\text { http://www.opengroup.org/ }\end{array}$ & $\begin{array}{l}\text { Approved status through } \\
\text { March } 2014\end{array}$ \\
\hline 6 & $\begin{array}{l}\text { Organization for the Advancement of Structured } \\
\text { Information Standards (OASIS) http://www.oasis-open.org/ }\end{array}$ & $\begin{array}{l}\text { Reaffirmed through } \\
\text { May } 2015\end{array}$ \\
\hline 7 & $\begin{array}{l}\text { The Open Group (The Open Group ) } \\
\text { http://www.opengroup.org/ }\end{array}$ & $\begin{array}{l}\text { Reaffirmed through } \\
\text { July } 2015\end{array}$ \\
\hline 8 & $\begin{array}{l}\text { Trusted Computing Group (TCG) } \\
\text { https://www.trustedcomputinggroup.org/home }\end{array}$ & $\begin{array}{l}\text { Reaffirmed through } \\
\text { February } 2016\end{array}$ \\
\hline 9 & $\begin{array}{l}\text { Universal Plug and Play Forum (UPnP Forum ) } \\
\text { http://www.upnp.org/ }\end{array}$ & $\begin{array}{l}\text { Approved status through } \\
\text { August } 2018\end{array}$ \\
\hline \multicolumn{3}{|c|}{$\begin{array}{l}{ }^{35} \text { More information can be found at } \underline{\text { http: }: / \text { isotc.iso.org/livelink/livelink/fetch/2000/2122/327993/755080/2317216/ }} \\
\text { Approved_PAS_Submitters.html?nodeid=2315468\&vernum }=0\end{array}$} \\
\hline \multicolumn{3}{|c|}{ 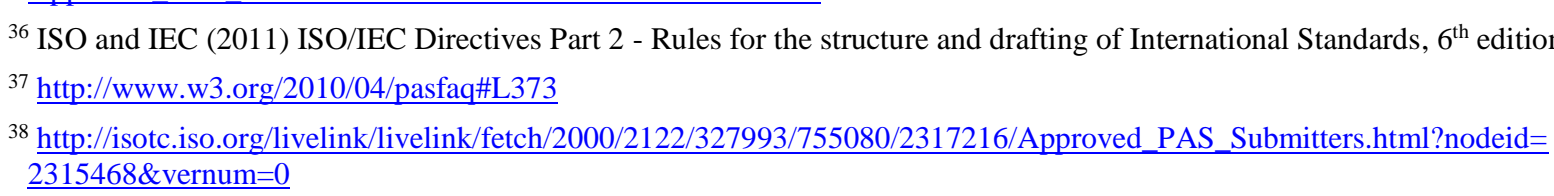 } \\
\hline
\end{tabular}




\begin{tabular}{lll}
\hline 10 & $\begin{array}{l}\text { World Wide Web Consortium (W3C) } \\
\text { http://www.w3.org/ }\end{array}$ & $\begin{array}{l}\text { Reaffirmed through } \\
\text { November } 2017\end{array}$ \\
\hline
\end{tabular}

\subsection{OGC's Agreement with ISO/TC211 Since 199840}

Other than traditional standards developing organizations, there are other forms of consortia that have worked closely with ISO or IEC committees for standards development. These may include EPCglobal (a joint venture between GS1 (formerly known as EAN International) and GS1 US (formerly the Uniform Code Council, Inc.) with JTC1/SC31 for Radio Frequency Identification (RFID) standards ${ }^{41}$, and the Open Geospatial Consortium (OGC) with ISO/TC211 for geographic information system standards. The OGC is an international industry consortium of 478 companies, government agencies, and universities participating in a consensus process to develop publicly available interface standards (www.opengeospatial.org).

ISO/TC 211 (Geographic information/Geomatics) and the OGC established a cooperative agreement in 1998. The purpose of this agreement is to establish an understanding between ISO/TC 211 and the OGC. This agreement formalizes the intention of ISO/TC 211 and OGC to cooperate and enables the development of a series of agreed specifications based on other related standards.

Under this agreement, the OGC has adopted five ISO/TC 211 standards as abstract specifications on which to base its own work on implementation of specifications. Also, a number of standards initially developed by the OGC have been brought to ISO/TC 211 and, after further development, published as ISO International Standards. These include eight ISO/TC211 standards and two draft standards, including ISO 19123 and ISO $19142^{42}$.

\section{Use of ISO and IEC Standards in the USA}

\subsection{Adoption of ISO and IEC Standards as American National Standards (ANS)}

\subsubsection{Alignment of ANS with ISO and IEC Increased}

In the U.S.A., the number of ISO and IEC standards adopted as ANS rapidly increased from $15(0.2 \%)$ out of some 8,500 standards in 1987, $150(1.3 \%)$ out of around 11,500 standards in 1996, to $1,576(15.5 \%)$ out of 10,144 ANS in May 2012 (See Table 12).

The current alignment ratio (15.5\%) of the U.S.A. is low compared to major trade partners of the U.S.A. Canada adopted 1,376 ISO standards, representing $36.4 \%$ of its 3,776 national standards ${ }^{43}$ at the end of Dec

\footnotetext{
${ }^{40}$ More information can be found at http://www.isotc211.org/Agreements/Agreement_OGC.pdf

${ }^{41}$ In July 2006, the EPC Gen 2 protocol was approved and adopted by the International Standards Organization as ISO 18000-6C standard.

${ }^{42}$ More information can be found at Standards Guide -- ISO TC 211 Geographic Information/Geomatics (see page 98), available at http://www.isotc211.org/Outreach/ISO_TC_211_Standards_Guide.pdf

${ }^{43}$ ISO, 2009, ISO Members
} 
2008, and today it is estimated that around $35 \%$ of national standards of Canada are harmonized with ISO and IEC $^{44}$. Other trading partners have similar high rates of harmonization. In 2009, the rate of ISO/IEC harmonization was $28 \%$ by China, $63 \%$ by Japan, and $55 \%$ by Korea. ${ }^{45}$. In Europe, $41.8 \%$ of the European Committee for Standardization (CEN) and the European Committee for Electrotechnical Standardization (CENELEC) standards are identical to ISO and IEC standards, and $56.1 \%$ are based on ISO and IEC standards ${ }^{46}$. The still relatively low formal adoption of ISO and IEC standards in the U.S.A. is likely an outcome of our unique and diverse standards system with some 230 ANSI-accredited standards developers, many of which develop ANS and other standards that are also used globally. ANSI, as the sole U.S.A. Member Body to ISO, and through the USNC to IEC, has the rights to nationally adopt ISO and IEC standards. However, ANSI does not develop or adopt standards itself and, instead, may assign its rights to nationally adopt an ISO or IEC document to an ANSI-Accredited Standards Developer (ASD). Eligible ASDs adopt identical or modified ISO and IEC documents as ANS.

Table 12 ANS $^{47}$ Adoption from ISO, IEC Standards (1987, 1996, 2012)

\begin{tabular}{llll}
\hline Total & $\mathbf{1 9 8 7}^{\mathbf{4 8}}$ & $\mathbf{1 9 9 6}^{\mathbf{4 9}}$ & May 2012 $^{\mathbf{5 0}}$ \\
\hline ANS (ANSI) & 8,500 (estimation) & 11,500 (estimation) & 10,144 \\
ANS adoption from ISO, IEC & 15 & 150 (estimation) & 1,576 \\
Adoption ratio (\%) & $0.2 \%$ & $1.3 \%$ & $15.5 \%$ \\
\hline
\end{tabular}

\subsubsection{The Case of UL: Adoption or Alignment?}

The adoption of ISO or IEC standards as ANS may not be a simple, one-way process, but an interactive cooperation or alignment process. In addition to the organizational agreement-based cooperation described in Section 5, there have been different types of cooperation by U.S.A.-domiciled SDOs. Such cooperation may result in alignment of ISO or IEC standards with the US-domiciled SDO's standards. The case described here of UL standards alignment with IEC standards is part of the 10,144 ANS adoption in Table 12.

\footnotetext{
44 The Canadian Standards Strategy since 2000 has promoted the adoption of international standards.

${ }^{45}$ Two internal survey reports in 2005 and 2010 conducted by Korean Standards Association (KSA). This data was provided by the author Dr. Dong Geun Choi.

${ }^{46}$ CEN-CENELEC, 2012, CEN-CENELEC Quarterly Statistical Pack for 2012 Quarter 2, available at http://www.cencenelec.eu/aboutus/InFigures/Pages/default.aspx.

${ }^{47}$ ANSI approved standards. Its designation procedure is available at www.ansi.org.

${ }^{48}$ Cooke, Patrick W. (1988) “A Review of U.S. Participation in International Standards Activities (NBSIR 88-2698)”, NIST: Gaithersburg.

${ }^{49}$ Toth, B. (1996). NIST Special Publication 912 "Profiles of National Standards-Related Activities" (See the section of the United States, page 144), available at http://gsi.nist.gov/global/docs/pubs/NISTSP_912.pdf

50 The statistics and comments are from personal communication with Gary Kushnier and Anne Caldas of ANSI.
} 


\subsubsection{52 UL-IEC Aligned Standards ${ }^{51}$}

UL is a global independent company in existence for more than 100 years. UL has aligned quite a few of their standards with relevant IEC standards. As of Jan 2014, there are over 75 UL/IEC standards, as listed in UL's standards catalogue ${ }^{52}$. UL/IEC standards are U.S.A. adoptions of the IEC standards, with U.S.A. national differences. These 52 UL-IEC harmonized standards include UL 60065 'Standard for Audio, Video and Similar Electronic Apparatus - Safety Requirements' (IEC 60065) and UL 62108 'Concentrator Photovoltaic (CPV) Modules and Assemblies - Design Qualification and Type Approval’ (IEC 62108).

\subsection{Referencing ISO and IEC Standards in U.S.A. Regulations}

Since the late 1990s, the NTTAA legislation and OMB Circular A-119 have served to significantly improve the efficiency of the U.S.A. federal government's use of standards in regulations by requiring federal agencies to select voluntary consensus standards whenever possible instead of developing unique government standards. NIST coordinates and monitors the implementation of the NTTAA within U.S.A. federal agencies, and maintains the Standards Incorporated by Reference (SIBR) ${ }^{53}$ database for informational purposes. The SIBR notes the number of times an SDO has a standard incorporated into a regulation and how often the standard is referenced in the Code of Federal Regulations (CFR). A standard may be referenced more than once in the CFR. According to the SIBR, 3,644 ${ }^{54}$ voluntary consensus standards have been incorporated by reference, and these standards have been cited a total of 9,486 times in the CFR as of July 2012.

As indicated in Table 13, the number of ISO and IEC standards annually incorporated by reference into U.S.A. regulations more than doubled from 70 standards and 205 citations in January 2002 to 172 standards and 419 citations in July 2012. The total number of all standards incorporated by reference and cited in the CFR held steady during the years (3,763 standards, 9,477 citations in 2002 and 3,644 standards, 9,486 citations in 2012). Therefore the ratio of the total incorporated and cited ISO and IEC standards compared to all incorporated and cited standards in the CFR more than doubled from $1.86 \%$ (70 out of 3,763) to $4.72 \%$ (172 out of 3,644) incorporated, and from $2.16 \%$ (205 out of 9,477) to $4.42 \%$ (419 out of 9,486) cited. The use of ISO and IEC standards in the U.S.A. regulations has increased in actual numbers and in frequency.

\footnotetext{
${ }^{51}$ Source: http://ulstandardsinfonet.ul.com/catalog/

${ }^{52}$ Source: http://ulstandardsinfonet.ul.com/catalog/stduliec.html

${ }^{53}$ The SIBR Database Administration System is operated by NIST, available at http://standards.gov/sibr/query/index.cfm.

${ }^{54}$ The number of standards can vary by counting method for different parts of a standard, or old-newer versions of one standard.
} 
Table 13 ISO and IEC Standards Incorporated by Reference in the U.S.A. Regulations ${ }^{55}$

\begin{tabular}{lllll}
\hline Classification & $\begin{array}{l}\text { Number of } \\
\text { Standards }\end{array}$ & \multicolumn{3}{c}{$\begin{array}{l}\text { Instances of } \\
\text { References }\end{array}$} \\
\hline Year & $\mathbf{2 0 0 2}$ & $\mathbf{2 0 1 2}$ & $\mathbf{2 0 0 2}$ & $\mathbf{2 0 1 2}$ \\
Total Standards Incorporated & 3,763 & 3,644 & 9,477 & 9,486 \\
Total ISO \& IEC Standards Incorporated & 70 & 172 & 205 & 419 \\
$\begin{array}{l}\text { Ratio of Total ISO \& IEC Standards Incorporated } \\
\text { Compared to All Standards Incorporated }\end{array}$ & $1.86 \%$ & $4.72 \%$ & $2.16 \%$ & $4.42 \%$ \\
\hline
\end{tabular}

\section{Summary}

\subsection{Participation in ISO and IEC}

This report compared the U.S.A.'s past and current participation with that of other countries in the two international standardization organizations, ISO and IEC.

As of Dec 2012, the U.S.A. has 71 (76.3\%) P-members out of 224 TCs in ISO, and $162(86.6 \%)$ out of 187 TC/SCs in IEC. Figure 3 shows that the P-memberships of the U.S.A. in ISO and IEC have increased since 1986. The ratio has been calculated by the number of TCs for ISO $(1986,1998$, and 2012) and IEC (1998). The ratio for IEC in 1986 and 2012 were calculated with the number of TCs plus SCs due to the data availability.

\begin{tabular}{|c|c|c|c|}
\hline \multicolumn{4}{|c|}{ P-membership of in ISO and IEC (1986-2012) } \\
\hline \multirow{5}{*}{$\begin{array}{r}100.0 \% \\
90.0 \% \\
80.0 \% \\
70.0 \% \\
60.0 \% \\
50.0 \%\end{array}$} & & & \\
\hline & & -8 & $-86.6 \%$ \\
\hline & 69 & -7 & $76.3 \%$ \\
\hline & 68 & & \\
\hline & 1986 & 1998 & 2012 \\
\hline$\Rightarrow-150$ & $68.9 \%$ & $73.9 \%$ & $76.3 \%$ \\
\hline$-\mathrm{IEC}$ & $69.0 \%$ & $86.5 \%$ & $86.6 \%$ \\
\hline
\end{tabular}

Figure 3 U.S.A. P-Memberships in ISO and IEC Increased in 1986 to 2012

U.S.A. holds 117 (15.9\%) out of 737 ISO secretariats, ranking $2^{\text {nd }}$ behind by Germany; and $24^{\text {th }}$ $(12.8 \%)$ out of 187 IEC secretariats, ranking $4^{\text {th }}$ behind Germany, France, and Japan. Figure 4 shows U.S.A. secretariats had increased by 1998, but declined from 1998 to 2012. The 2012 data for ISO is

\footnotetext{
55 This table is based on the SIBR Database internally available at NIST. The 2002 data is as of January 2002 , and the 2012 data is as of July 2012. While NIST makes every effort to continuously update the SIBR Database to reflect changes to standards referenced in the CFR, NIST cannot guarantee the accuracy or completeness of the SIBR Database.
} 
based on its 2011 Annual Report (Jan 2012) and for IEC is based on its 2012 Activity Report (Sep 2012).

\begin{tabular}{|c|c|c|c|c|}
\hline \multicolumn{5}{|c|}{ Secretariatship in ISO and IEC (1966-2012) } \\
\hline \multirow{4}{*}{$\begin{array}{r}25.0 \% \\
20.0 \% \\
15.0 \% \\
10.0 \% \\
5.0 \% \\
0.0 \%\end{array}$} & \multirow[b]{2}{*}{$8.5 \%$} & \multicolumn{3}{|c|}{$18.3 \%$} \\
\hline & & & $=-\frac{1}{16}$ & $=15.9 \%$ \\
\hline & \multicolumn{4}{|l|}{$8.5 \%$} \\
\hline & 1066 & 1006 & & \\
\hline & & & & \\
\hline$=-\mathrm{ISO}$ & $8.5 \%$ & $10.5 \%$ & $18.3 \%$ & $15.9 \%$ \\
\hline$-1 \mathrm{IEC}$ & $7.8 \%$ & $16.3 \%$ & $16.8 \%$ & $12.8 \%$ \\
\hline
\end{tabular}

Figure 4 U.S.A. Secretariats Increased in 1966 to 1998, and Declined in 1998 to 2012

Also, U.S.A. holds 509 (20.2 \%) out of 2,516 ISO WG convenors, ranking $1^{\text {st }}$ in the world; and 31 $(16.6 \%)$ out of 187 IEC TC/SC chairs, ranking $2^{\text {nd }}$ behind Germany. Figure 5 shows that USA's convenors in ISO WGs have slightly decreased by $0.9 \%$ while chairs in IEC TC/SCs have increased by 3.6\% during 1998-2012. The 2012 data for ISO is based on its 2011 Annual Report (Jan 2012) and for IEC is based on its 2012 Activity Report (Sep 2012).

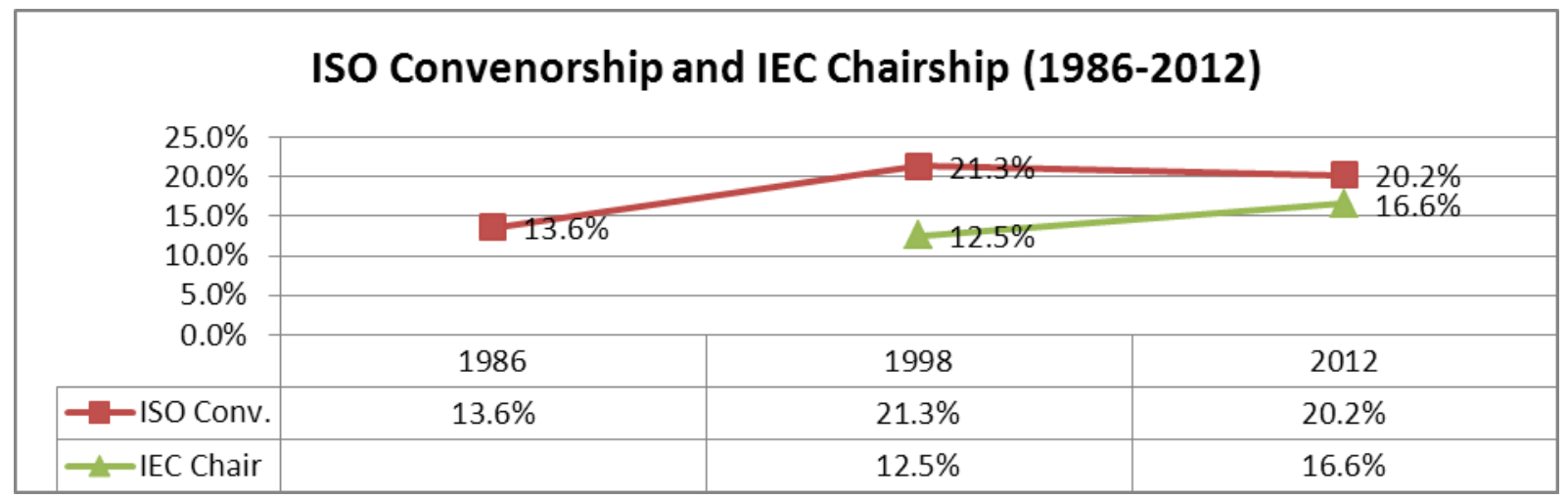

Figure 5 U.S.A. Convenor in ISO Decreased and Chair in IEC Increased in 1998 to 2012

\subsection{Agreement-Based Participation in ISO and IEC}

In addition to ANSI and USNC, the U.S.A. participates in ISO and IEC through cooperative agreements negotiated by U.S.A.-domiciled standards organizations. This report includes descriptions of five agreements by three standards developers. Table 14 presents the five agreement-based SDO entities that jointly developed (adopted) 114 standards. In addition to these five agreements is the PAS Submitter procedure for JTC1, which produced 115 PASs. 
Table 14 Agreement-Based Participation in ISO and IEC

\begin{tabular}{lll}
\hline SDOs & Agreement Type & Related Standards \\
\hline IEEE-ISO & PSDO Agreement (2008 to present) & 51 standards \\
IEEE-ISO & Dual Logo Agreement (2002 to present) & 23 standards \\
ASTM-ISO (TC85) & Pilot Program (1999 to 2004) & 25 standards \\
ASTM-ISO (TC261) & PSDO Agreement (2011 to present) & (under development) \\
OGC-ISO TC211 & Cooperative Agreement (1998) & 15 standards \\
\cline { 2 - 2 } & & 114 standards \\
\hline
\end{tabular}

\subsection{U.S.A. Standards and Regulations Aligned with ISO and IEC Standards}

In 1986, there were only 15 ANS adopted from ISO, constituting only $0.2 \%$ of 8,400 ANS ${ }^{56}$. As presented in Figure 6, the number of ISO or IEC standards adopted as ANS increased to150 (1.3\%) out of 11,500 in 1996, and then to 1,576 (15.5\%) out of 10,144 ANS as of May 2012. The adoption of ISO or IEC standards as ANS may be a more interactive cooperation or alignment process; such cooperation may result in alignment of ISO or IEC standards with the standards of US-domiciled SDOs, including 85 API/ISO standards and 52 UL/IEC standards.

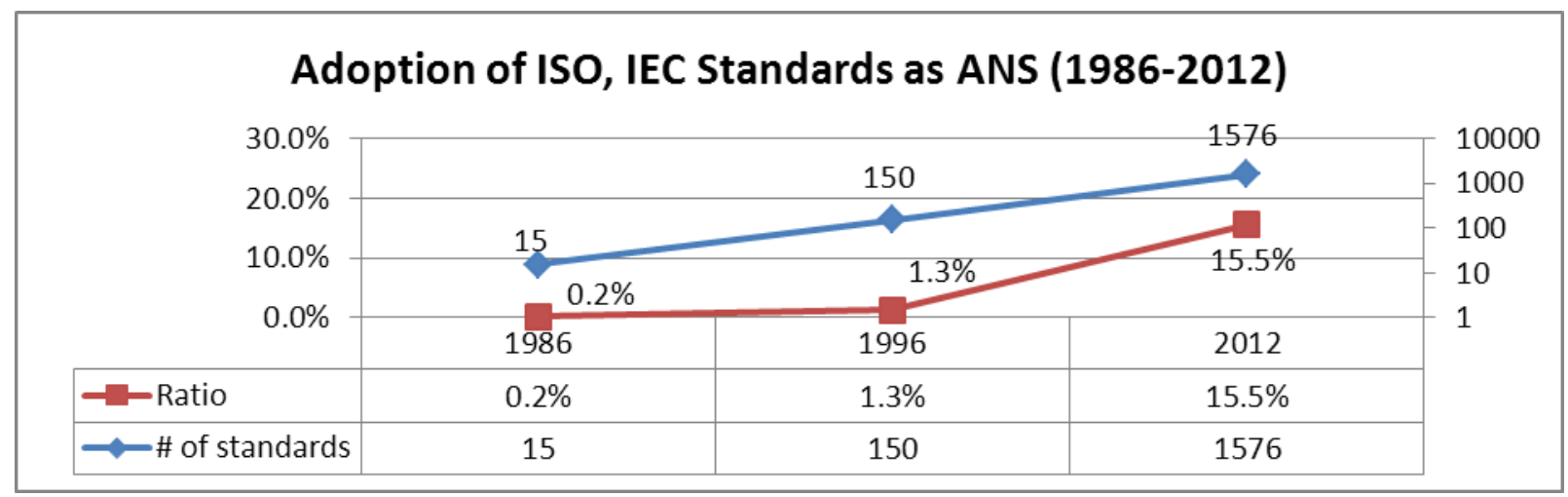

Figure 6 Adoption of ISO and IEC 1986-2012

According to the Standards Incorporated by Reference (SIBR) ${ }^{57}$ database operated by NIST, the use of ISO and IEC standards in U.S.A. regulations has more than doubled during 2002 to 2012 in actual numbers and in its frequency. Figure 7 proves that the frequency of ISO and IEC standards incorporated in the SIBR database more than doubled from $1.86 \%$ (70 out of 3,763$)$ to $4.72 \%(172$ out of 9,477$)$ and from $2.16 \%$ (205 out of 9,477$)$ to $4.42 \%(419$ out of 9,486$)$ by the number of standards referenced.

\footnotetext{
${ }^{56}$ The list of the 15 ANS/ISO standards is available at Table 5 (p. 61) in the Cooke, Patrick W. (1988). See footnote 26.

${ }^{57}$ The SIBR Database Administration System is operated by NIST, available at http://standards.gov/sibr/query/index.cfm.
} 


\begin{tabular}{|c|c|c|c|}
\hline \multicolumn{4}{|c|}{ Incorporation by Reference of ISO, IEC Standards (2002-2012) } \\
\hline \multirow{5}{*}{$\begin{array}{r}20.0 \% \\
15.0 \% \\
10.0 \% \\
5.0 \% \\
0.0 \%\end{array}$} & \multirow{2}{*}{\multicolumn{2}{|c|}{ 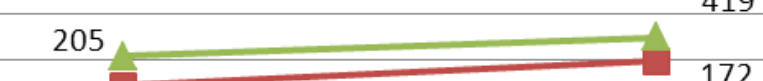 }} & \multirow{8}{*}{$\begin{array}{l}1,000 \\
100 \\
10 \\
1\end{array}$} \\
\hline & & & \\
\hline & 70 & & \\
\hline & \multicolumn{2}{|c|}{$2.2 \% \times \times 4.4 \%$} & \\
\hline & 2002 & 2012 & \\
\hline$\longleftarrow \%$ composition & $2.2 \%$ & $4.4 \%$ & \\
\hline$\rightarrow$ \# Standards & 70 & 172 & \\
\hline- \# Referencing & 205 & 419 & \\
\hline
\end{tabular}

Figure 7 Incorporation by Reference of ISO and IEC 2002-2012 


\section{Annex 1. Membership Comparison of ISO, IEC, and UN (Dec 2012)}

Membership comparison is based on the websites of ISO and IEC, both accessed on Dec 31, 2012.

\begin{tabular}{|c|c|c|c|c|c|}
\hline Country & $\begin{array}{l}\text { ISO }^{58} \\
\text { Memb. }\end{array}$ & $\begin{array}{l}\text { IEC } \\
\text { Memb. }\end{array}$ & $\begin{array}{l}\text { ISO }^{60} \\
\text { Comm. }\end{array}$ & $\begin{array}{l}\text { IEC }{ }^{61} \\
\text { Comm. }\end{array}$ & $\begin{array}{l}\text { UN }^{62} \\
\text { Memb. }\end{array}$ \\
\hline Afghanistan & Correspond & - & 0 & - & Yes \\
\hline Albania & Correspond & Associate & 4 & 2 & Yes \\
\hline Algeria & Full & Full & 56 & 2 & Yes \\
\hline Andorra & - & - & - & - & Yes \\
\hline Angola & Correspond & - & 1 & - & Yes \\
\hline Antigua and Barbuda & Subscriber & - & 0 & - & Yes \\
\hline Argentina & Full & Full & 345 & 21 & Yes \\
\hline Armenia & Full & - & 41 & - & Yes \\
\hline Australia & Full & Full & 439 & 139 & Yes \\
\hline Austria & Full & Full & 531 & 165 & Yes \\
\hline Azerbaijan & Full & - & 10 & - & Yes \\
\hline Bahamas & - & - & - & - & Yes \\
\hline Bahrain & Full & Associate & 9 & 0 & Yes \\
\hline Bangladesh & Full & - & 20 & - & Yes \\
\hline Barbados & Full & - & 34 & - & Yes \\
\hline Belarus & Full & Full & 163 & 40 & Yes \\
\hline Belgium & Full & Full & 545 & 168 & Yes \\
\hline Belize & - & - & - & - & Yes \\
\hline Benin & Correspond & - & 1 & - & Yes \\
\hline Bhutan & Correspond & - & 6 & - & Yes \\
\hline Bolivia & Correspond & - & 12 & - & Yes \\
\hline $\begin{array}{l}\text { Bosnia and } \\
\text { Herzegovina }\end{array}$ & Full & Associate & 90 & 2 & Yes \\
\hline Botswana & Full & - & 30 & - & Yes \\
\hline Brazil & Full & Full & 326 & 117 & Yes \\
\hline Brunei Darussalam & Correspond & - & 5 & - & Yes \\
\hline Bulgaria & Full & Full & 357 & 148 & Yes \\
\hline Burkina Faso & Correspond & - & 2 & - & Yes \\
\hline
\end{tabular}

\footnotetext{
${ }^{58}$ ISO Membership (164 countries); Full: Full member (member body) (112) (Correspond: Correspondent member (48); Subscriber: Subscriber member (4); -: not a member (32).

${ }^{59}$ IEC Membership (82 countries); Full: Full member (60); Associate: Associate member (22); -: not a member (114).

${ }^{60}$ ISO Committee participation: P-membership + O-membership.

${ }^{61}$ IEC Committee participation: P-membership + O-membership.

${ }^{62}$ UN Membership: UN has 193 members in 2012, and three ISO correspondent members listed here are not UN members - Hong Kong, China; Macau, China; Palestine.
} 


\begin{tabular}{|c|c|c|c|c|c|}
\hline Burundi & Correspond & - & 2 & - & Yes \\
\hline Cambodia & Correspond & - & 0 & - & Yes \\
\hline Cameroon & Full & - & 33 & - & Yes \\
\hline Canada & Full & Full & 361 & 115 & Yes \\
\hline Cape Verde & - & - & - & - & Yes \\
\hline $\begin{array}{l}\text { Central African } \\
\text { Republic }\end{array}$ & - & - & - & - & Yes \\
\hline Chad & - & - & - & - & Yes \\
\hline Chile & Full & Full & 115 & 2 & Yes \\
\hline China & Full & Full & 706 & 177 & Yes \\
\hline Colombia & Full & Full & 145 & 11 & Yes \\
\hline Comoros & - & - & - & - & Yes \\
\hline $\begin{array}{l}\text { Congo, The } \\
\text { Democratic Republic of } \\
\text { the }\end{array}$ & Full & - & 16 & - & Yes \\
\hline $\begin{array}{l}\text { Congo, the Republic of } \\
\text { the }\end{array}$ & Correspond & - & 1 & - & Yes \\
\hline Costa Rica & Full & - & 28 & - & Yes \\
\hline Côte d'Ivoire & Full & - & 51 & - & Yes \\
\hline Croatia & Full & Full & 184 & 69 & Yes \\
\hline Cuba & Full & Associate & 202 & 5 & Yes \\
\hline Cyprus & Full & Associate & 78 & 2 & Yes \\
\hline Czech Republic & Full & Full & 595 & 175 & Yes \\
\hline Denmark & Full & Full & 324 & 173 & Yes \\
\hline Djibouti & - & - & - & - & Yes \\
\hline Dominica & Correspond & - & 0 & - & Yes \\
\hline Dominican Republic & Correspond & - & 1 & - & Yes \\
\hline Ecuador & Full & - & 93 & - & Yes \\
\hline Egypt & Full & Full & 291 & 49 & Yes \\
\hline EI Salvador & Correspond & - & 9 & - & Yes \\
\hline Equatorial Guinea & - & - & - & - & Yes \\
\hline Eritrea & Correspond & - & 1 & - & Yes \\
\hline Estonia & Full & Associate & 76 & 0 & Yes \\
\hline Ethiopia & Full & - & 128 & - & Yes \\
\hline Fiji & Full & - & 10 & - & Yes \\
\hline Finland & Full & Full & 560 & 173 & Yes \\
\hline France & Full & Full & 724 & 177 & Yes \\
\hline Gabon & Full & - & 6 & - & Yes \\
\hline Gambia & Correspond & - & 2 & - & Yes \\
\hline Georgia & Correspond & Associate & 1 & 0 & Yes \\
\hline Germany & Full & Full & 718 & 177 & Yes \\
\hline Ghana & Full & - & 28 & - & Yes \\
\hline Greece & Full & Full & 196 & 107 & Yes \\
\hline
\end{tabular}




\begin{tabular}{|c|c|c|c|c|c|}
\hline Grenada & - & - & - & - & Yes \\
\hline Guatemala & Correspond & - & 0 & - & Yes \\
\hline Guinea & Correspond & - & 0 & - & Yes \\
\hline Guinea-Bissau & - & - & - & - & Yes \\
\hline Guyana & Correspond & - & 0 & - & Yes \\
\hline Haiti & - & - & - & - & Yes \\
\hline Honduras & Subscriber & - & 0 & - & Yes \\
\hline Hong Kong, China & 2.Corr, & - & 237 & - & - \\
\hline Hungary & Full & Full & 480 & 140 & Yes \\
\hline Iceland & Full & Associate & 152 & 2 & Yes \\
\hline India & Full & Full & 610 & 155 & Yes \\
\hline Indonesia & Full & Full & 223 & 67 & Yes \\
\hline $\begin{array}{l}\text { Iran, Islamic Republic } \\
\text { of }\end{array}$ & Full & Full & 399 & 46 & Yes \\
\hline Iraq & Full & Full & 35 & 7 & Yes \\
\hline Ireland & Full & Full & 286 & 116 & Yes \\
\hline Israel & Full & Full & 221 & 96 & Yes \\
\hline Italy & Full & Full & 666 & 177 & Yes \\
\hline Jamaica & Full & - & 101 & & Yes \\
\hline Japan & Full & Full & 687 & 176 & Yes \\
\hline Jordan & Full & Associate & 22 & 4 & Yes \\
\hline Kazakhstan & Full & Associate & 78 & 4 & Yes \\
\hline Kenya & Full & Associate & 206 & 5 & Yes \\
\hline Kiribati & - & - & - & - & Yes \\
\hline $\begin{array}{l}\text { Korea, Democratic } \\
\text { People's Republic }\end{array}$ & Full & - & 95 & - & Yes \\
\hline Korea, Republic of & Full & Full & 711 & 174 & Yes \\
\hline Kuwait & Full & - & 7 & - & Yes \\
\hline Kyrgyzstan & Correspond & - & 0 & - & Yes \\
\hline $\begin{array}{l}\text { Lao People's } \\
\text { Democratic Rep. }\end{array}$ & Subscriber & - & 0 & - & Yes \\
\hline Latvia & Correspond & Associate & 3 & 0 & Yes \\
\hline Lebanon & Full & - & 20 & - & Yes \\
\hline Lesotho & Correspond & - & 3 & - & Yes \\
\hline Liberia & Correspond & - & 0 & - & Yes \\
\hline Libya & Full & Full & 36 & 0 & Yes \\
\hline Liechtenstein & - & - & & - & Yes \\
\hline Lithuania & Full & Associate & 61 & 0 & Yes \\
\hline Luxembourg & Full & Full & 57 & 5 & Yes \\
\hline Macau, China & Correspond & - & 0 & - & - \\
\hline Madagascar & Correspond & - & 1 & - & Yes \\
\hline Malawi & Correspond & - & 3 & - & Yes \\
\hline Malaysia & Full & Full & 265 & 105 & Yes \\
\hline
\end{tabular}




\begin{tabular}{|c|c|c|c|c|c|}
\hline Maldives & - & - & - & - & Yes \\
\hline Mali & Full & - & 11 & - & Yes \\
\hline Malta & Full & Associate & 40 & 4 & Yes \\
\hline Marshall Islands & - & - & - & - & Yes \\
\hline Mauritania & Correspond & - & 2 & - & Yes \\
\hline Mauritius & Full & - & 67 & - & Yes \\
\hline Mexico & Full & Full & 99 & 90 & Yes \\
\hline $\begin{array}{l}\text { Micronesia (Federated } \\
\text { States of) }\end{array}$ & - & - & - & - & Yes \\
\hline Moldova, Republic of & Correspond & Associate & 41 & 3 & Yes \\
\hline Monaco & - & - & - & - & Yes \\
\hline Mongolia & Full & - & 147 & - & Yes \\
\hline Montenegro & Correspond & Associate & 11 & 0 & Yes \\
\hline Morocco & Full & Associate & 74 & 0 & Yes \\
\hline Mozambique & Correspond & - & 2 & - & Yes \\
\hline Myanmar & Correspond & - & 0 & - & Yes \\
\hline Namibia & Full & - & 17 & - & Yes \\
\hline Nauru & - & - & - & - & Yes \\
\hline Nepal & Correspond & - & 1 & - & Yes \\
\hline Netherlands & Full & Full & 596 & 159 & Yes \\
\hline New Zealand & Full & Full & 167 & 120 & Yes \\
\hline Nicaragua & Correspond & - & 0 & - & Yes \\
\hline Niger & Correspond & - & 0 & - & Yes \\
\hline Nigeria & Full & Associate & 33 & 3 & Yes \\
\hline Norway & Full & Full & 371 & 165 & Yes \\
\hline Oman & Full & Full & 23 & 27 & Yes \\
\hline Pakistan & Full & Full & 158 & 68 & Yes \\
\hline Palau & - & - & - & - & Yes \\
\hline Palestine & Correspond & - & 5 & - & - \\
\hline Panama & Full & - & 2 & - & Yes \\
\hline Papua New Guinea & Correspond & - & 1 & - & Yes \\
\hline Paraguay & Correspond & - & 0 & - & Yes \\
\hline Peru & Full & - & 23 & - & Yes \\
\hline $\begin{array}{l}\text { Philippines, Republic of } \\
\text { the }\end{array}$ & Full & Full & 118 & 7 & Yes \\
\hline Poland & Full & Full & 643 & 175 & Yes \\
\hline Portugal & Full & Full & 348 & 127 & Yes \\
\hline Qatar & Full & Full & 27 & 1 & Yes \\
\hline Romania & Full & Full & 687 & 162 & Yes \\
\hline Russian Federation & Full & Full & 622 & 168 & Yes \\
\hline Rwanda & Correspond & - & 4 & - & Yes \\
\hline Saint Kitts and Nevis & - & - & - & - & Yes \\
\hline
\end{tabular}




\begin{tabular}{|c|c|c|c|c|c|}
\hline Saint Lucia & Full & - & 5 & - & Yes \\
\hline $\begin{array}{l}\text { Saint Vincent and the } \\
\text { Grenadines }\end{array}$ & Subscriber & - & 0 & - & Yes \\
\hline Samoa & - & - & - & - & Yes \\
\hline San Marino & - & - & - & - & Yes \\
\hline Sao Tome and Principe & - & - & - & - & Yes \\
\hline Saudi Arabia & Full & Full & 160 & 19 & Yes \\
\hline Senegal & Full & - & 6 & - & Yes \\
\hline Serbia & Full & Full & 471 & 152 & Yes \\
\hline Seychelles & Correspond & - & 3 & - & Yes \\
\hline Sierra Leone & Correspond & - & 2 & - & Yes \\
\hline Singapore & Full & Full & 139 & 96 & Yes \\
\hline Slovakia & Full & Full & 444 & 101 & Yes \\
\hline Slovenia & Full & Full & 77 & 93 & Yes \\
\hline Solomon Islands & - & - & - & - & Yes \\
\hline Somalia & - & - & - & - & Yes \\
\hline South Africa & Full & Full & 431 & 127 & Yes \\
\hline South Sudan & - & - & - & - & Yes \\
\hline Spain & Full & Full & 625 & 176 & Yes \\
\hline Sri Lanka & Full & Associate & 160 & 4 & Yes \\
\hline Sudan & Full & - & 11 & - & Yes \\
\hline Suriname & Correspond & - & 0 & - & Yes \\
\hline Swaziland & Correspond & - & 13 & - & Yes \\
\hline Sweden & Full & Full & 536 & 176 & Yes \\
\hline Switzerland & Full & Full & 540 & 147 & Yes \\
\hline Syrian Arab Republic & Full & - & 18 & - & Yes \\
\hline Tajikistan & Correspond & - & 11 & - & Yes \\
\hline $\begin{array}{l}\text { Tanzania, United } \\
\text { Republic of }\end{array}$ & Full & - & 141 & - & Yes \\
\hline Thailand & Full & Full & 280 & 79 & Yes \\
\hline $\begin{array}{l}\text { The former Yugoslav } \\
\text { Republic of Macedonia }\end{array}$ & Full & Associate & 10 & 1 & Yes \\
\hline Timor-Leste & - & - & - & - & Yes \\
\hline Togo & Correspond & - & 1 & - & Yes \\
\hline Tonga & - & - & - & - & Yes \\
\hline Trinidad and Tobago & Full & - & 72 & - & Yes \\
\hline Tunisia & Full & Associate & 163 & 4 & Yes \\
\hline Turkey & Full & Full & 365 & 91 & Yes \\
\hline Turkmenistan & Correspond & - & 0 & - & Yes \\
\hline Tuvalu & - & - & - & - & Yes \\
\hline Uganda & Full & - & 22 & - & Yes \\
\hline Ukraine & Full & Full & 337 & 160 & Yes \\
\hline United Arab Emirates & Full & Full & 20 & 0 & Yes \\
\hline
\end{tabular}




\begin{tabular}{llllll}
\hline United Kingdom & Full & Full & 726 & 175 & Yes \\
Uruguay & Full & - & 52 & - & Yes \\
USA & Full & Full & 620 & 162 & Yes \\
Uzbekistan & Full & - & 7 & - & Yes \\
Vanuatu & - & - & - & - & Yes \\
$\begin{array}{l}\text { Venezuela (Bolivarian } \\
\text { Republic of) }\end{array}$ & - & - & - & - & Yes \\
Viet Nam & Full & Associate & 73 & 4 & Yes \\
Yemen & Full & - & 5 & - & Yes \\
Zambia & Correspond & - & 6 & - & Yes \\
Zimbabwe & Full & - & 49 & - & Yes \\
Total & $\mathbf{1 6 4}$ & $\mathbf{8 2}$ & - & - & $\mathbf{1 9 3}$ \\
& members & members & & & members \\
\hline
\end{tabular}




\section{Annex 2. List of ISO and IEC Technical Committees}

\section{A2.1 List of 224 ISO Technical Committees (Dec 2012)}

\begin{tabular}{|c|c|c|c|}
\hline TC \# & TC's Title & $\begin{array}{l}\text { Standards } \\
\text { published }\end{array}$ & $\begin{array}{l}\text { Work } \\
\text { program }\end{array}$ \\
\hline JTC 1 & Information technology & 2574 & 573 \\
\hline JPC 2 & $\begin{array}{l}\text { Joint Project Committee - Energy efficiency and } \\
\text { renewable energy sources - Common terminology }\end{array}$ & 0 & 2 \\
\hline TC 1 & Screw threads & 23 & 2 \\
\hline TC 2 & Fasteners & 188 & 7 \\
\hline TC 4 & Rolling bearings & 76 & 12 \\
\hline TC 5 & Ferrous metal pipes and metallic fittings & 67 & 2 \\
\hline TC 6 & Paper, board and pulps & 175 & 34 \\
\hline TC 8 & Ships and marine technology & 273 & 70 \\
\hline TC 10 & Technical product documentation & 144 & 18 \\
\hline TC 11 & Boilers and pressure vessels & 2 & 0 \\
\hline TC 12 & Quantities and units & 16 & 8 \\
\hline TC 14 & Shafts for machinery and accessories & 8 & 0 \\
\hline TC 17 & Steel & 316 & 56 \\
\hline TC 18 & Zinc and zinc alloys - STANDBY & 11 & 0 \\
\hline TC 19 & Preferred numbers - STANDBY & 3 & 0 \\
\hline TC 20 & Aircraft and space vehicles & 560 & 109 \\
\hline TC 21 & Equipment for fire protection and fire fighting & 98 & 7 \\
\hline TC 22 & Road vehicles & 745 & 198 \\
\hline TC 23 & Tractors and machinery for agriculture and forestry & 340 & 79 \\
\hline TC 24 & Particle characterization including sieving & 54 & 13 \\
\hline TC 25 & Cast irons and pig irons & 16 & 2 \\
\hline TC 26 & Copper and copper alloys & 38 & 0 \\
\hline TC 27 & Solid mineral fuels & 104 & 8 \\
\hline TC 28 & Petroleum products and lubricants & 247 & 24 \\
\hline TC 29 & Small tools & 418 & 88 \\
\hline TC 30 & Measurement of fluid flow in closed conduits & 44 & 7 \\
\hline TC 31 & Tires, rims and valves & 75 & 17 \\
\hline TC 33 & Refractories & 80 & 6 \\
\hline TC 34 & Food products & 796 & 82 \\
\hline TC 35 & Paints and varnishes & 234 & 37 \\
\hline TC 36 & Cinematography & 118 & 3 \\
\hline TC 37 & Terminology and other language and content resources & 39 & 16 \\
\hline TC 38 & Textiles & 356 & 56 \\
\hline TC 39 & Machine tools & 161 & 26 \\
\hline TC 41 & Pulleys and belts (including veebelts) & 81 & 20 \\
\hline
\end{tabular}




\begin{tabular}{|c|c|c|c|}
\hline TC 42 & Photography & 179 & 22 \\
\hline TC 43 & Acoustics & 196 & 40 \\
\hline TC 44 & Welding and allied processes & 292 & 50 \\
\hline TC 45 & Rubber and rubber products & 434 & 42 \\
\hline TC 46 & Information and documentation & 113 & 18 \\
\hline TC 47 & Chemistry & 118 & 0 \\
\hline TC 48 & Laboratory equipment & 110 & 0 \\
\hline TC 51 & Pallets for unit load method of materials handling & 15 & 5 \\
\hline TC 52 & Light gauge metal containers & 13 & 0 \\
\hline TC 54 & Essential oils & 129 & 9 \\
\hline TC 58 & Gas cylinders & 91 & 32 \\
\hline TC 59 & Buildings and civil engineering works & 112 & 16 \\
\hline TC 60 & Gears & 67 & 8 \\
\hline TC 61 & Plastics & 625 & 84 \\
\hline TC 63 & Glass containers & 29 & 3 \\
\hline TC 67 & $\begin{array}{l}\text { Materials, equipment and offshore structures for } \\
\text { petroleum, petrochemical and natural gas industries }\end{array}$ & 182 & 74 \\
\hline TC 68 & Financial services & 48 & 28 \\
\hline TC 69 & Applications of statistical methods & 93 & 28 \\
\hline TC 70 & Internal combustion engines & 63 & 12 \\
\hline TC 71 & Concrete, reinforced concrete and pre-stressed concrete & 30 & 22 \\
\hline TC 72 & Textile machinery and accessories & 184 & 11 \\
\hline TC 74 & Cement and lime & 8 & 0 \\
\hline TC 76 & $\begin{array}{l}\text { Transfusion, infusion and injection, and blood processing } \\
\text { equipment for medical and pharmaceutical use }\end{array}$ & 61 & 5 \\
\hline TC 77 & Products in fiber reinforced cement & 7 & 0 \\
\hline TC 79 & Light metals and their alloys & 114 & 4 \\
\hline TC 81 & Common names for pesticides and other agrochemicals & 10 & 2 \\
\hline TC 82 & Mining & 36 & 0 \\
\hline TC 83 & Sports and recreational equipment & 68 & 8 \\
\hline TC 84 & $\begin{array}{l}\text { Devices for administration of medicinal products and } \\
\text { intravascular catheters }\end{array}$ & 36 & 13 \\
\hline TC 85 & $\begin{array}{l}\text { Nuclear energy, nuclear technologies, and radiological } \\
\text { protection }\end{array}$ & 175 & 54 \\
\hline TC 86 & Refrigeration and air-conditioning & 23 & 12 \\
\hline TC 87 & Cork & 46 & 2 \\
\hline TC 89 & Wood-based panels & 42 & 8 \\
\hline TC 91 & Surface active agents & 77 & 4 \\
\hline TC 92 & Fire safety & 115 & 33 \\
\hline TC 93 & Starch (including derivatives and by-products) & 26 & 2 \\
\hline TC 94 & Personal safety -- Protective clothing and equipment & 109 & 46 \\
\hline ТC 96 & Cranes & 103 & 14 \\
\hline TC 98 & Bases for design of structures & 20 & 5 \\
\hline
\end{tabular}




\begin{tabular}{|c|c|c|c|}
\hline TC 100 & $\begin{array}{l}\text { Chains and chain sprockets for power transmission and } \\
\text { conveyors }\end{array}$ & 17 & 3 \\
\hline TC 101 & Continuous mechanical handling equipment & 37 & 0 \\
\hline TC 102 & Iron ore and direct reduced iron & 71 & 21 \\
\hline TC 104 & Freight containers & 52 & 5 \\
\hline TC 105 & Steel wire ropes & 26 & 2 \\
\hline TC 106 & Dentistry & 162 & 40 \\
\hline TC 107 & Metallic and other inorganic coatings & 134 & 11 \\
\hline TC 108 & Mechanical vibration, shock and condition monitoring & 157 & 21 \\
\hline TC 109 & Oil and gas burners & 2 & 0 \\
\hline TC 110 & Industrial trucks & 54 & 17 \\
\hline TC 111 & $\begin{array}{l}\text { Round steel link chains, chain slings, components and } \\
\text { accessories }\end{array}$ & 20 & 3 \\
\hline TC 112 & Vacuum technology & 21 & 3 \\
\hline TC 113 & Hydrometry & 72 & 10 \\
\hline TC 114 & Horology & 32 & 1 \\
\hline TC 115 & Pumps & 24 & 3 \\
\hline TC 117 & Fans & 24 & 6 \\
\hline TC 118 & $\begin{array}{l}\text { Compressors and pneumatic tools, machines and } \\
\text { equipment }\end{array}$ & 69 & 15 \\
\hline TC 119 & Powder metallurgy & 74 & 9 \\
\hline TC 120 & Leather & 21 & 6 \\
\hline TC 121 & Anesthetic and respiratory equipment & 84 & 32 \\
\hline TC 122 & Packaging & 73 & 18 \\
\hline TC 123 & Plain bearings & 74 & 2 \\
\hline TC 126 & Tobacco and tobacco products & 68 & 10 \\
\hline TC 127 & Earth-moving machinery & 157 & 35 \\
\hline TC 129 & Aluminum ores - STANDBY & 17 & 0 \\
\hline TC 130 & Graphic technology & 70 & 21 \\
\hline TC 131 & Fluid power systems & 218 & 47 \\
\hline TC 132 & Ferroalloys & 31 & 0 \\
\hline TC 133 & Sizing systems and designations for clothes & 15 & 3 \\
\hline TC 134 & Fertilizers and soil conditioners & 30 & 5 \\
\hline TC 135 & Non-destructive testing & 71 & 26 \\
\hline TC 136 & Furniture & 25 & 2 \\
\hline TC 137 & Footwear sizing designations and marking systems & 1 & 1 \\
\hline TC 138 & $\begin{array}{l}\text { Plastics pipes, fittings and valves for the transport of } \\
\text { fluids }\end{array}$ & 309 & 37 \\
\hline TC 142 & Cleaning equipment for air and other gases & 8 & 14 \\
\hline TC 145 & Graphical symbols & 27 & 134 \\
\hline TC 146 & Air quality & 135 & 31 \\
\hline TC 147 & Water quality & 268 & 40 \\
\hline TC 148 & Sewing machines & 9 & 0 \\
\hline
\end{tabular}




\begin{tabular}{|c|c|c|c|}
\hline TC 149 & Cycles & 16 & 17 \\
\hline TC 150 & Implants for surgery & 135 & 36 \\
\hline TC 153 & Valves & 25 & 10 \\
\hline TC 154 & $\begin{array}{l}\text { Processes, data elements and documents in commerce, } \\
\text { industry and administration }\end{array}$ & 26 & 2 \\
\hline TC 155 & Nickel and nickel alloys & 55 & 2 \\
\hline TC 156 & Corrosion of metals and alloys & 63 & 28 \\
\hline TC 157 & $\begin{array}{l}\text { Non-systemic contraceptives and STI barrier } \\
\text { prophylactics }\end{array}$ & 13 & 1 \\
\hline TC 158 & Analysis of gases & 23 & 6 \\
\hline TC 159 & Ergonomics & 119 & 15 \\
\hline TC 160 & Glass in building & 40 & 9 \\
\hline TC 161 & $\begin{array}{l}\text { Control and protective devices for gas and/or oil burners } \\
\text { and appliances }\end{array}$ & 10 & 4 \\
\hline TC 162 & Doors and windows & 21 & 1 \\
\hline TC 163 & $\begin{array}{l}\text { Thermal performance and energy use in the built } \\
\text { environment }\end{array}$ & 104 & 26 \\
\hline TC 164 & Mechanical testing of metals & 81 & 37 \\
\hline TC 165 & Timber structures & 30 & 12 \\
\hline TC 166 & $\begin{array}{l}\text { Ceramic ware, glassware and glass ceramic ware in } \\
\text { contact with food }\end{array}$ & 6 & 0 \\
\hline TC 167 & Steel and aluminum structures & 4 & 0 \\
\hline TC 168 & Prosthetics and orthotics & 21 & 3 \\
\hline TC 170 & Surgical instruments & 6 & 0 \\
\hline TC 171 & Document management applications & 81 & 6 \\
\hline TC 172 & Optics and photonics & 290 & 60 \\
\hline TC 173 & Assistive products for persons with disability & 73 & 12 \\
\hline TC 174 & Jewelry & 17 & 12 \\
\hline TC 176 & Quality management and quality assurance & 22 & 6 \\
\hline TC 178 & Lifts, escalators and moving walks & 33 & 5 \\
\hline TC 179 & Masonry - STANDBY & 3 & 0 \\
\hline TC 180 & Solar energy & 16 & 6 \\
\hline TC 181 & Safety of toys & 5 & 8 \\
\hline TC 182 & Geotechnics & 48 & 17 \\
\hline TC 183 & Copper, lead, zinc and nickel ores and concentrates & 23 & 6 \\
\hline TC 184 & Automation systems and integration & 749 & 62 \\
\hline TC 185 & Safety devices for protection against excessive pressure & 14 & 6 \\
\hline TC 186 & Cutlery and table and decorative metal hollow-ware & 9 & 0 \\
\hline TC 188 & Small craft & 101 & 15 \\
\hline TC 189 & Ceramic tile & 26 & 21 \\
\hline TC 190 & Soil quality & 138 & 42 \\
\hline TC 191 & Animal (mammal) traps - STANDBY & 2 & 0 \\
\hline TC 192 & Gas turbines & 16 & 3 \\
\hline
\end{tabular}




\begin{tabular}{|c|c|c|c|}
\hline TC 193 & Natural gas & 53 & 9 \\
\hline TC 194 & Biological evaluation of medical devices & 30 & 2 \\
\hline TC 195 & Building construction machinery and equipment & 31 & 10 \\
\hline TC 197 & Hydrogen technologies & 17 & 6 \\
\hline TC 198 & Sterilization of health care products & 45 & 17 \\
\hline TC 199 & Safety of machinery & 44 & 13 \\
\hline TC 201 & Surface chemical analysis & 52 & 19 \\
\hline TC 202 & Microbeam analysis & 19 & 3 \\
\hline TC 203 & Technical energy systems & 5 & 0 \\
\hline TC 204 & Intelligent transport systems & 139 & 94 \\
\hline TC 205 & Building environment design & 17 & 7 \\
\hline TC 206 & Fine ceramics & 60 & 31 \\
\hline TC 207 & Environmental management & 29 & 10 \\
\hline TC 208 & $\begin{array}{l}\text { Thermal turbines for industrial application (steam } \\
\text { turbines, gas expansion turbines) - STANDBY }\end{array}$ & 2 & 0 \\
\hline TC 209 & Cleanrooms and associated controlled environments & 12 & 7 \\
\hline TC 210 & $\begin{array}{l}\text { Quality management and corresponding general aspects } \\
\text { for medical devices }\end{array}$ & 18 & 12 \\
\hline TC 211 & Geographic information/Geomatics & 65 & 20 \\
\hline TC 212 & $\begin{array}{l}\text { Clinical laboratory testing and in vitro diagnostic test } \\
\text { systems }\end{array}$ & 25 & 5 \\
\hline TC 213 & $\begin{array}{l}\text { Dimensional and geometrical product specifications and } \\
\text { verification }\end{array}$ & 117 & 46 \\
\hline TC 214 & Elevating work platforms & 8 & 3 \\
\hline TC 215 & Health informatics & 113 & 55 \\
\hline TC 216 & Footwear & 69 & 15 \\
\hline TC 217 & Cosmetics & 21 & 6 \\
\hline TC 218 & Timber & 59 & 16 \\
\hline TC 219 & Floor coverings & 73 & 10 \\
\hline TC 220 & Cryogenic vessels & 20 & 4 \\
\hline TC 221 & Geosynthetics & 34 & 13 \\
\hline TC 222 & Personal financial planning - STANDBY & 1 & 0 \\
\hline TC 223 & Societal security & 7 & 6 \\
\hline TC 224 & $\begin{array}{l}\text { Service activities relating to drinking water supply } \\
\text { systems and wastewater systems - Quality criteria of the } \\
\text { service and performance indicators }\end{array}$ & 3 & 1 \\
\hline TC 225 & Market, opinion and social research & 2 & 0 \\
\hline TC 226 & Materials for the production of primary aluminum & 113 & 7 \\
\hline TC 227 & Springs & 4 & 2 \\
\hline TC 228 & Tourism and related services & 12 & 14 \\
\hline TC 229 & Nanotechnologies & 33 & 13 \\
\hline TC 232 & Learning services for non-formal education and training & 1 & 1 \\
\hline TC 234 & Fisheries and aquaculture & 3 & 8 \\
\hline
\end{tabular}




\begin{tabular}{|c|c|c|c|}
\hline TC 236 & Project Committee: Project Management & 1 & 0 \\
\hline TC 238 & Solid biofuels & 0 & 28 \\
\hline TC 240 & Project Committee: Product recall & 0 & 1 \\
\hline TC 241 & Road traffic safety management systems & 1 & 0 \\
\hline TC 242 & Energy Management & 1 & 5 \\
\hline TC 243 & Project Committee: Consumer product safety & 0 & 1 \\
\hline TC 244 & Industrial furnaces and associated processing equipment & 5 & 4 \\
\hline TC 245 & $\begin{array}{l}\text { Project Committee: Cross-border trade of second-hand } \\
\text { goods }\end{array}$ & 0 & 1 \\
\hline TC 247 & Fraud countermeasures and controls & 1 & 3 \\
\hline TC 248 & Project committee: Sustainability criteria for bioenergy & 0 & 1 \\
\hline TC 249 & Traditional Chinese medicine & 0 & 2 \\
\hline TC 250 & Project committee: Sustainability in event management & 1 & 0 \\
\hline TC 251 & Project committee: Asset management & 0 & 3 \\
\hline TC 252 & $\begin{array}{l}\text { Project committee: Natural gas fuelling stations for } \\
\text { vehicles }\end{array}$ & 0 & 2 \\
\hline TC 253 & $\begin{array}{l}\text { Project committee: Treated wastewater re-use for } \\
\text { irrigation }\end{array}$ & 0 & 5 \\
\hline TC 254 & Safety of amusement rides and amusement devices & 0 & 3 \\
\hline TC 255 & Biogas & 0 & 0 \\
\hline TC 256 & Pigments, dyestuffs and extenders & 84 & 0 \\
\hline TC 257 & $\begin{array}{l}\text { General technical rules for determination of energy } \\
\text { savings in renovation projects, industrial enterprises and } \\
\text { regions }\end{array}$ & 0 & 4 \\
\hline TC 258 & Project, program and portfolio management & 0 & 1 \\
\hline TC 259 & Project committee: Outsourcing & 0 & 1 \\
\hline TC 260 & Human resource management & 0 & 2 \\
\hline TC 261 & Additive manufacturing & 0 & 7 \\
\hline TC 262 & Risk management & 2 & 1 \\
\hline TC 263 & Coalbed methane (CBM) & 0 & 0 \\
\hline TC 264 & Fireworks & 0 & 0 \\
\hline TC 265 & $\begin{array}{l}\text { Carbon dioxide capture, transportation, and geological } \\
\text { storage }\end{array}$ & 0 & 0 \\
\hline TC 266 & Biomimetics & 0 & 3 \\
\hline TC 267 & Facilities management & 0 & 2 \\
\hline TC 268 & Sustainable development in communities & 0 & 2 \\
\hline TC 269 & Railway applications & 0 & 0 \\
\hline TC 270 & Plastic and rubber machines & 0 & 0 \\
\hline PC 271 & Compliance programs & 0 & 1 \\
\hline PC 272 & Forensic sciences & 0 & 1 \\
\hline PC 273 & Customer contact centers & 0 & 0 \\
\hline TC 274 & Light and lighting & 0 & 0 \\
\hline
\end{tabular}




\section{A2.2 List of 97 IEC Technical Committees (Dec 2012)}

\begin{tabular}{|c|c|c|c|c|}
\hline TC \# & TC's Title & $\begin{array}{l}\text { P- \& O- } \\
\text { Members }\end{array}$ & $\begin{array}{l}\text { Standards } \\
\text { published }\end{array}$ & $\begin{array}{l}\text { Work } \\
\text { program }\end{array}$ \\
\hline $\begin{array}{l}\text { ISO/IEC } \\
\text { JTC } 1\end{array}$ & Information technology & 0 & 498 & 0 \\
\hline $\begin{array}{l}\text { ISO/IEC } \\
\text { JPC } 2\end{array}$ & $\begin{array}{l}\text { Energy efficiency and renewable energy } \\
\text { sources - Common international terminology }\end{array}$ & 40 & 0 & 2 \\
\hline TC 1 & Terminology & 38 & 110 & 8 \\
\hline TC 2 & Rotating machinery & 45 & 63 & 9 \\
\hline TC 3 & $\begin{array}{l}\text { Information structures, documentation and } \\
\text { graphical symbols }\end{array}$ & 31 & 44 & 13 \\
\hline TC 4 & Hydraulic turbines & 34 & 32 & 3 \\
\hline TC 5 & Steam turbines & 26 & 7 & 0 \\
\hline TC 7 & Overhead electrical conductors & 37 & 30 & 5 \\
\hline TC 8 & Systems aspects for electrical energy supply & 44 & 7 & 4 \\
\hline TC 9 & Electrical equipment and systems for railways & 39 & 84 & 39 \\
\hline TC 10 & Fluids for electrotechnical applications & 40 & 53 & 4 \\
\hline TC 11 & Overhead lines & 38 & 16 & 1 \\
\hline TC 13 & $\begin{array}{l}\text { Electrical energy measurement, tariff- and load } \\
\text { control }\end{array}$ & 47 & 53 & 16 \\
\hline TC 14 & Power transformers & 47 & 45 & 9 \\
\hline TC 15 & Solid electrical insulating materials & 39 & 219 & 15 \\
\hline TC 17 & Switchgear and controlgear & 49 & 0 & 0 \\
\hline TC 18 & $\begin{array}{l}\text { Electrical installations of ships and of mobile } \\
\text { and fixed offshore units }\end{array}$ & 30 & 42 & 13 \\
\hline TC 20 & Electric cables & 53 & 209 & 15 \\
\hline TC 21 & Secondary cells and batteries & 42 & 43 & 9 \\
\hline TC 22 & Power electronic systems and equipment & 38 & 10 & 2 \\
\hline TC 23 & Electrical accessories & 52 & 5 & 2 \\
\hline TC 25 & Quantities and units & 27 & 38 & 10 \\
\hline TC 26 & Electric welding & 29 & 19 & 9 \\
\hline TC 27 & $\begin{array}{l}\text { Industrial electroheating and electromagnetic } \\
\text { processing }\end{array}$ & 27 & 31 & 10 \\
\hline TC 28 & Insulation co-ordination & 38 & 10 & 1 \\
\hline TC 29 & Electroacoustics & 36 & 63 & 10 \\
\hline TC 31 & Equipment for explosive atmospheres & 46 & 41 & 17 \\
\hline TC 32 & Fuses & 43 & 2 & 0 \\
\hline TC 33 & Power capacitors and their applications & 36 & 25 & 10 \\
\hline TC 34 & Lamps and related equipment & 48 & 3 & 1 \\
\hline TC 35 & Primary cells and batteries & 38 & 8 & 1 \\
\hline TC 36 & Insulators & 45 & 11 & 2 \\
\hline TC 37 & Surge arresters & 43 & 14 & 3 \\
\hline
\end{tabular}




\begin{tabular}{|c|c|c|c|c|}
\hline TC 38 & Instrument transformers & 44 & 10 & 9 \\
\hline TC 40 & $\begin{array}{l}\text { Capacitors and resistors for electronic } \\
\text { equipment }\end{array}$ & 30 & 198 & 19 \\
\hline TC 42 & High-voltage and high-current test techniques & 40 & 14 & 6 \\
\hline TC 44 & Safety of machinery - Electrotechnical aspects & 34 & 25 & 8 \\
\hline TC 45 & Nuclear instrumentation & 33 & 37 & 2 \\
\hline TC 46 & $\begin{array}{l}\text { Cables, wires, waveguides, R.F. connectors, } \\
\text { R.F. and microwave passive components and } \\
\text { accessories }\end{array}$ & 39 & 37 & 13 \\
\hline TC 47 & Semiconductor devices & 31 & 87 & 13 \\
\hline TC 48 & $\begin{array}{l}\text { Electromechanical components and mechanical } \\
\text { structures for electronic equipment }\end{array}$ & 33 & 0 & 0 \\
\hline TC 49 & $\begin{array}{l}\text { Piezoelectric, dielectric and electrostatic } \\
\text { devices and associated materials for frequency } \\
\text { control, selection and detection }\end{array}$ & 25 & 82 & 12 \\
\hline TC 51 & Magnetic components and ferrite materials & 25 & 83 & 1 \\
\hline TC 55 & Winding wires & 34 & 141 & 21 \\
\hline TC 56 & Dependability & 36 & 64 & 10 \\
\hline TC 57 & $\begin{array}{l}\text { Power systems management and associated } \\
\text { information exchange }\end{array}$ & 44 & 119 & 40 \\
\hline TC 59 & $\begin{array}{l}\text { Performance of household and similar } \\
\text { electrical appliances }\end{array}$ & 43 & 25 & 3 \\
\hline TC 61 & $\begin{array}{l}\text { Safety of household and similar electrical } \\
\text { appliances }\end{array}$ & 53 & 187 & 8 \\
\hline TC 62 & Electrical equipment in medical practice & 44 & 4 & 0 \\
\hline TC 64 & $\begin{array}{l}\text { Electrical installations and protection against } \\
\text { electric shock }\end{array}$ & 50 & 74 & 9 \\
\hline TC 65 & $\begin{array}{l}\text { Industrial-process measurement, control and } \\
\text { automation }\end{array}$ & 40 & 15 & 13 \\
\hline TC 66 & $\begin{array}{l}\text { Safety of measuring, control and laboratory } \\
\text { equipment }\end{array}$ & 35 & 21 & 10 \\
\hline TC 68 & Magnetic alloys and steels & 28 & 42 & 5 \\
\hline TC 69 & $\begin{array}{l}\text { Electric road vehicles and electric industrial } \\
\text { trucks }\end{array}$ & 39 & 8 & 20 \\
\hline TC 70 & Degrees of protection provided by enclosures & 37 & 5 & 1 \\
\hline TC 72 & Automatic electrical controls & 33 & 28 & 3 \\
\hline TC 73 & Short-circuit currents & 35 & 19 & 2 \\
\hline TC 76 & Optical radiation safety and laser equipment & 37 & 29 & 7 \\
\hline TC 77 & Electromagnetic compatibility & 50 & 15 & 1 \\
\hline TC 78 & Live working & 40 & 68 & 10 \\
\hline TC 79 & Alarm and electronic security systems & 37 & 40 & 17 \\
\hline TC 80 & $\begin{array}{l}\text { Maritime navigation and radio communication } \\
\text { equipment and systems }\end{array}$ & 33 & 49 & 9 \\
\hline TC 81 & Lightning protection & 47 & 15 & 4 \\
\hline TC 82 & Solar photovoltaic energy systems & 48 & 64 & 38 \\
\hline TC 85 & Measuring equipment for electrical and & 36 & 62 & 21 \\
\hline
\end{tabular}




\begin{tabular}{|c|c|c|c|c|}
\hline & electromagnetic quantities & & & \\
\hline TC 86 & Fiber optics & 42 & 20 & 6 \\
\hline TC 87 & Ultrasonics & 34 & 40 & 9 \\
\hline TC 88 & Wind turbines & 38 & 25 & 13 \\
\hline TC 89 & Fire hazard testing & 36 & 48 & 17 \\
\hline TC 90 & Superconductivity & 25 & 15 & 6 \\
\hline TC 91 & Electronics assembly technology & 32 & 180 & 36 \\
\hline ТC 94 & All-or-nothing electrical relays & 31 & 19 & 6 \\
\hline TC 95 & Measuring relays and protection equipment & 33 & 24 & 6 \\
\hline TC 96 & $\begin{array}{l}\text { Transformers, reactors, power supply units, } \\
\text { and combinations thereof }\end{array}$ & 31 & 23 & 3 \\
\hline TC 97 & $\begin{array}{l}\text { Electrical installations for lighting and } \\
\text { beaconing of aerodromes }\end{array}$ & 24 & 5 & 1 \\
\hline TC 99 & $\begin{array}{l}\text { System engineering and erection of electrical } \\
\text { power installations in systems with nominal } \\
\text { voltages above } 1 \mathrm{kV} \text { a.c. and } 1,5 \mathrm{kV} \text { d.c., } \\
\text { particularly concerning safety aspects }\end{array}$ & 30 & 2 & 2 \\
\hline TC 100 & $\begin{array}{l}\text { Audio, video and multimedia systems and } \\
\text { equipment }\end{array}$ & 44 & 439 & 65 \\
\hline TC 101 & Electrostatics & 32 & 23 & 7 \\
\hline TC 103 & $\begin{array}{l}\text { Transmitting equipment for radio } \\
\text { communication }\end{array}$ & 29 & 41 & 5 \\
\hline TC 104 & $\begin{array}{l}\text { Environmental conditions, classification and } \\
\text { methods of test }\end{array}$ & 27 & 118 & 9 \\
\hline TC 105 & Fuel cell technologies & 31 & 13 & 7 \\
\hline TC 106 & $\begin{array}{l}\text { Methods for the assessment of electric, } \\
\text { magnetic and electromagnetic fields associated } \\
\text { with human exposure }\end{array}$ & 34 & 15 & 9 \\
\hline TC 107 & Process management for avionics & 19 & 17 & 12 \\
\hline TC 108 & $\begin{array}{l}\text { Safety of electronic equipment within the field } \\
\text { of audio/video, information technology and } \\
\text { communication technology }\end{array}$ & 41 & 31 & 3 \\
\hline TC 109 & $\begin{array}{l}\text { Insulation co-ordination for low-voltage } \\
\text { equipment }\end{array}$ & 33 & 10 & 1 \\
\hline TC 110 & Electronic display devices & 26 & 103 & 28 \\
\hline TC 111 & $\begin{array}{l}\text { Environmental standardization for electrical } \\
\text { and electronic products and systems }\end{array}$ & 33 & 7 & 13 \\
\hline TC 112 & $\begin{array}{l}\text { Evaluation and qualification of electrical } \\
\text { insulating materials and systems }\end{array}$ & 30 & 68 & 9 \\
\hline TC 113 & $\begin{array}{l}\text { Nanotechnology standardization for electrical } \\
\text { and electronic products and systems }\end{array}$ & 32 & 4 & 17 \\
\hline TC 114 & $\begin{array}{l}\text { Marine energy - Wave, tidal and other water } \\
\text { current converters }\end{array}$ & 22 & 2 & 9 \\
\hline TC 115 & $\begin{array}{l}\text { High Voltage Direct Current (HVDC) } \\
\text { transmission for DC voltages above } 100 \mathrm{kV}\end{array}$ & 23 & 0 & 2 \\
\hline TC 116 & Safety of motor-operated electric tools & 45 & 83 & 6 \\
\hline TC 117 & Solar thermal electric plants & 22 & 0 & 0 \\
\hline
\end{tabular}




\begin{tabular}{lllll}
\hline PC 118 & Smart grid user interface & 25 & 0 & 0 \\
TC 119 & Printed Electronics & 18 & 0 & 0 \\
TC 120 & Electrical Energy Storage (EES) Systems & 20 & 0 & 0 \\
CISPR & International special committee on radio & 40 & 0 & 0 \\
& interference & & & \\
\hline
\end{tabular}




\section{A2.3 List of Subcommittees in ISO/IEC JTC 1 and JPC 1 (Dec 2012) ${ }^{63,64}$}

\begin{tabular}{|c|c|c|c|c|}
\hline Committee & Description & Secretariat & Chairman & $\begin{array}{l}\text { Publication } \\
\text { s }\end{array}$ \\
\hline JTC 1 & Information technology & ANSI & USA & 498 \\
\hline - SC 2 & Coded character sets & JISC & Japan & 35 \\
\hline - SC 6 & $\begin{array}{l}\text { Telecommunications and information } \\
\text { exchange between systems }\end{array}$ & KATS & Korea & 346 \\
\hline - SC 7 & Software engineering & $\mathrm{SCC}$ & Canada & 150 \\
\hline - SC 17 & Cards and personal identification & BSI & UK & 105 \\
\hline - SC 22 & $\begin{array}{l}\text { Programming languages, their environments } \\
\text { and system software interfaces }\end{array}$ & ANSI & USA & 85 \\
\hline - SC 23 & $\begin{array}{l}\text { Optical disk cartridges for information } \\
\text { interchange }\end{array}$ & JISC & Japan & 107 \\
\hline - SC 24 & Computer graphics and image processing & BSI & Korea & 75 \\
\hline - SC 25 & $\begin{array}{l}\text { Interconnection of information technology } \\
\text { equipment }\end{array}$ & DIN & Germany & 255 \\
\hline - SC 27 & IT security techniques & DIN & Germany & 128 \\
\hline - SC 28 & Office equipment & JISC & Japan & 31 \\
\hline - SC 29 & $\begin{array}{l}\text { Coding of audio, picture, multimedia and } \\
\text { hypermedia information }\end{array}$ & JISC & Japan & 487 \\
\hline - SC 31 & $\begin{array}{l}\text { Automatic identification and data capture } \\
\text { techniques }\end{array}$ & ANSI & USA & 101 \\
\hline - SC 32 & Data management services & ANSI & USA & 61 \\
\hline - SC 34 & $\begin{array}{l}\text { Document description and processing } \\
\text { languages }\end{array}$ & JISC & Korea & 59 \\
\hline - SC 35 & User interfaces & AFNOR & France & 59 \\
\hline - SC 36 & $\begin{array}{l}\text { Information technology for learning, } \\
\text { education and training }\end{array}$ & KATS & USA & 28 \\
\hline - SC 37 & Biometrics & ANSI & USA & 75 \\
\hline - SC 38 & $\begin{array}{l}\text { Distributed Application Platforms and } \\
\text { Services (DAPS) }\end{array}$ & ANSI & USA & 5 \\
\hline - SC 39 & $\begin{array}{l}\text { Sustainability for and by Information } \\
\text { Technology }\end{array}$ & ANSI & USA & 0 \\
\hline
\end{tabular}

\footnotetext{
${ }^{63}$ More information about JTC 1 is available at http://www.iso.org/iso/home/standards_development/list_of_iso_ technical committees/iso_technical_committee.htm?commid=45020

${ }^{64}$ More information about JTC 2 (JPC 2) is available at http://www.iso.org/iso/home/standards_development/ $\underline{\text { list of iso technical committees/iso technical committee.htm?commid=585141 }}$
} 


\begin{tabular}{lllll}
\hline JTC 2 & $\begin{array}{l}\text { Energy efficiency and renewable energy } \\
\text { sources - Common international } \\
\text { terminology }\end{array}$ & AFNOR & France & 0 \\
\hline
\end{tabular}

\section{Annex 3. List of U.S.A. Secretariats in ISO and IEC}

\section{A3.1 List of 121 ISO TC/SCs Whose Secretariat is the U.S.A. (Dec 2012) ${ }^{65}$}

JTC 1 - Information technology

JTC 1/SC 22 - Programming languages, their environments and system software interfaces

JTC 1/SC 31 - Automatic identification and data capture techniques

JTC 1/SC 32 - Data management and interchange

JTC 1/SC 37 - Biometrics

JTC 1/SC 38 - Distributed application platforms and services

JTC 1/SC 39 - Sustainability for and by Information Technology

TC 4/SC 6 - Insert bearings

TC 4/SC 9 - Tapered roller bearings

TC 4/SC 11 - Linear motion rolling bearings

TC 5/SC 10 - Metallic flanges and their joints

TC 8/SC 1 - Lifesaving and fire protection

TC 8/SC 2 - Marine environment protection

TC 8/SC 3 - Piping and machinery

TC 10/SC 1 - Basic conventions

TC 11 - Boilers and pressure vessels

TC 17/SC 11 - Steel castings

TC 17/SC 12 - Continuous mill flat rolled products

TC 18/SC 3Stand by - Zinc metal

TC 20 - Aircraft and space vehicles

TC 20/SC 13 - Space data and information transfer systems

TC 20/SC 14 - Space systems and operations

TC 20/SC 15 - Airframe bearings

TC 21/SC 5 - Fixed firefighting systems using water

TC 22/SC 10 - Impact test procedures

TC 22/SC 11 - Safety glazing materials

TC 22/SC 13 - Ergonomics applicable to road vehicles

TC 22/SC 19 - Wheels

TC 23/SC 2 - Common tests

TC 23/SC 13 - Powered lawn and garden equipment

TC 23/SC 14 - Operator controls, operator symbols and other displays, operator manuals

TC 28 - Petroleum products and lubricants

TC 28/SC 2 - Measurement of petroleum and related products

\footnotetext{
${ }^{65}$ Source: http://www.iso.org/iso/home/about/iso_members/iso_member_participation_tc.htm?member_id=2188. ISO Annual Report 2011 indicates that the number of U.S.A. Secretariats is 117 as of Dec 31, 2011. However, ISO website provides more recent data for secretariats. As of Dec 31, 2012, the U.S.A. held 121 secretariats as listed here.
} 
TC 28/SC 7 - Liquid Biofuels

TC 31 - Tires, rims and valves

TC 31/SC 8 - Aircraft tires and rims

TC 34/SC 16 - Horizontal methods for molecular biomarker analysis

TC 36 - Cinematography

TC 39/SC 2 - Test conditions for metal cutting machine tools

TC 41/SC 4 - Synchronous belt drives

TC 42 - Photography

TC 43/SC 3 - Underwater acoustics

TC 44/SC 3 - Welding consumables

TC 46/SC 9 - Identification and description

TC 58/SC 4 - Operational requirements for gas cylinders

TC 60 - Gears

TC 67/SC 4 - Drilling and production equipment

TC 68 - Financial services

TC 69/SC 1 - Terminology and symbols

TC 69/SC 4 - Applications of statistical methods in process management

TC 71 - Concrete, reinforced concrete and pre-stressed concrete

TC 71/SC 4 - Performance requirements for structural concrete

TC 79/SC 9 - Symbolization

TC 85/SC 6 - Reactor technology

TC 86 - Refrigeration and air-conditioning

TC 86/SC 1 - Safety and environmental requirements for refrigerating systems

TC 86/SC 2 - Terms and definitions

TC 86/SC 3 - Testing and rating of factory-made refrigeration systems

TC 86/SC 6 - Testing and rating of air-conditioners and heat pumps

TC 86/SC 7 - Testing and rating of commercial refrigerated display cabinets

TC 86/SC 8 - Refrigerants and refrigeration lubricants

TC 92/SC 2 - Fire containment

TC 92/SC 3 - Fire threat to people and environment

TC 94/SC 1 - Head protection

TC 96/SC 6 - Mobile cranes

TC 96/SC 8 - Jib cranes

TC 104 - Freight containers

TC 106/SC 2 - Prosthodontic materials

TC 106/SC 8 - Dental implants

TC 108 - Mechanical vibration, shock and condition monitoring

TC 108/SC 5 - Condition monitoring and diagnostics of machine systems

TC 113/SC 5 - Instruments, equipment and data management

TC 113/SC 8 - Ground water

TC 115/SC 3 - Installation and special application

TC 119/SC 5 - Specifications for powder metallurgical materials

TC 121 - Anesthetic and respiratory equipment 
TC 121/SC 2 - Airways and related equipment

TC 121/SC 3 - Lung ventilators and related equipment

TC 121/SC 4 - Terminology and semantics

TC 121/SC 6 - Medical gas systems

TC 127 - Earth-moving machinery

TC 127/SC 2 - Safety, ergonomics and general requirements

TC 131 - Fluid power systems

TC 131/SC 4 - Connectors and similar products and components

TC 131/SC 9 - Installations and systems

TC 145/SC 3 - Graphical symbols for use on equipment

TC 146/SC 2 - Workplace atmospheres

TC 146/SC 3 - Ambient atmospheres

TC 146/SC 5 - Meteorology

TC 150/SC 2 - Cardiovascular implants and extracorporeal systems

TC 150/SC 5 - Osteosynthesis and spinal devices

TC 150/SC 6 - Active implants

TC 160/SC 2 - Use considerations

TC 164/SC 4 - Toughness testing -- Fracture

TC 164/SC 5 - Fatigue testing

TC 171 - Document management applications

TC 171/SC 2 - Application issues

TC 180/SC 4 - Systems - Thermal performance, reliability and durability

TC 184/SC 4 - Industrial data

TC 184/SC 5 - Interoperability, integration, and architectures for enterprise systems and automation applications

TC 185 - Safety devices for protection against excessive pressure

TC 189 - Ceramic tile

TC 192 - Gas turbines

TC 193/SC 3 - Upstream area

TC 198 - Sterilization of health care products

TC 201/SC 1 - Terminology

TC 201/SC 2 - General procedures

TC 202/SC 1 - Terminology

TC 204 - Intelligent transport systems

TC 205 - Building environment design

TC 207/SC 4 - Environmental performance evaluation

TC 209 - Cleanrooms and associated controlled environments

TC 210 - Quality management and corresponding general aspects for medical devices

TC 212 - Clinical laboratory testing and in vitro diagnostic test systems

TC 214 - Elevating work platforms

TC 215 - Health informatics

TC 236 - Project Committee: Project Management

TC 242 - Energy Management 
TC 247 - Fraud countermeasures and controls

TC 258 - Project, program and portfolio management

TC 260 - Human resource management 


\section{A3.2. List of 24 IEC TC/SCs Whose Secretariat is the U.S.A. (Dec 2012)66}

TC 15 - Solid electrical insulating materials

TC 22/SC 22G - Adjustable speed electric drive systems incorporating semiconductor power converters

TC 37 - Surge arresters

TC 37/SC 37A - Low-voltage surge protective devices

TC 37/SC 37B - Specific components for surge arresters and surge protective devices

TC 46 - Cables, wires, waveguides, R.F. connectors, R.F. and microwave passive components and accessories

TC 48 - Electromechanical components and mechanical structures for electronic equipment

TC 48/SC 48B - Connectors

TC 55 - Winding wires

TC 61 - Safety of household and similar electrical appliances

TC 61/SC 61D - Appliances for air-conditioning for household and similar purposes

TC 62/SC 62A - Common aspects of electrical equipment used in medical practice

TC 62/SC 62D - Electromedical equipment

TC 65/SC 65B - Measurement and control devices

TC 65/SC 65E - Devices and integration in enterprise systems

TC 72 - Automatic electrical controls

TC 76 - Optical radiation safety and laser equipment

TC 82 - Solar photovoltaic energy systems

TC 86 - Fiber optics

TC 86/SC 86C - Fiber optic systems and active devices

TC 100/TA 2 - Color measurement and management

TC 108 - Safety of electronic equipment within the field of audio/video, information technology and communication technology

TC 116 - Safety of motor-operated electric tools

CISPR/CIS/A - Radio-interference measurements and statistical methods

${ }^{66}$ Source: http://www.iec.ch/dyn/www/f?p=103:34:0:.::FSP_ORG_ID,FSP_LANG_ID:1046,25. Both IEC Activity Report and Annual Report $($ Oct 5, 2012) and IEC website (Dec 31, 2012) indicates that the number of U.S. Secretariats is 24 as listed here. 


\section{Annex 4. ISO and IEC Standards Development Stages ${ }^{67}$}

This annex refers to ISO/IEC Directives, Part 1: Procedures for the technical work. An International Standard is the result of an agreement between the member bodies of ISO or national committees of IEC. It may be used as such, or may be implemented through incorporation of national standards in different countries. International standards are developed by ISO or IEC technical committees (TC) and subcommittees (SC) by a six-step process.

\section{A4.1 Proposal Stage}

The first step in the development of an international standard is to confirm that a particular international standard is needed. A new work item proposal (NP) is submitted for vote by the members of the relevant TC or SC to determine the inclusion of the work item in the program of work.

The proposal is accepted if a majority of the P-members of the TC/SC votes in favor and if at least five Pmembers declare their commitment to participate actively in the project. At this stage a project leader responsible for the work item is normally appointed.

\section{A4.2 Preparatory Stage}

Usually, a working group of experts, the chairman (convener) of which is the project leader, is set up by the TC/SC for the preparation of a working draft. Successive working drafts may be considered until the working group is satisfied that it has developed the best technical solution to the problem being addressed. At this stage, the draft is forwarded to the working group's parent committee for the consensus-building phase.

\section{A4.3 Committee Stage}

As soon as a first committee draft is available, it is registered by ISO Central Secretariat. It is distributed for comment and, if required, voting, by the P-members of the TC/SC. Successive committee drafts may be considered until consensus is reached on the technical content. Once consensus has been attained, the text is finalized for submission as a draft international standard (DIS).

\section{A4.4 Enquiry Stage}

The DIS is circulated to all ISO member bodies by ISO Central Secretariat for voting and comments within a period of five months. It is approved for submission as a final draft international standard (FDIS) if a twothirds majority of the P-members of the TC/SC are in favor and not more than one-quarter of the total number of votes cast are negative. If the approval criteria are not met, the text is returned to the originating

\footnotetext{
${ }^{67}$ More details of ISO and IEC standards development procedures and relevant rules can be found at the website: http://www.iso.org/iso/home/standards development/resources-for-technical-work/iso iec directives and iso supplement.htm
} 
TC/SC for further study and a revised document will again be circulated for voting and comment as a DIS.

\section{A4.5 Approval Stage}

The final draft international standard (FDIS) is circulated to all ISO member bodies by the ISO Central Secretariat for a final Yes/No vote within a period of two months. If technical comments are received during this period, they are no longer considered at this stage, but registered for consideration during a future revision of the international standard. The text is approved as an international standard if a two-thirds majority of the P-members of the TC/SC is in favor and not more than one-quarter of the total number of votes cast are negative. If these approval criteria are not met, the standard is referred back to the originating $\mathrm{TC} / \mathrm{SC}$ for reconsideration in light of the technical reasons submitted in support of the negative votes received.

\section{A4.6 Publication Stage}

Once a final draft international standard has been approved, only minor editorial changes, if necessary, are introduced into the final text. The final text is sent to the ISO Central Secretariat, who publishes the international standard.

\section{A4.7 Review of International Standards (Confirmation, Revision, Withdrawal)}

All international standards are reviewed at least every five years by all ISO member bodies. A majority of the P-members of the TC/SC decides whether an international standard should be confirmed, revised, or withdrawn.

\section{A4.8 Fast-Track Procedure}

If a document with a certain degree of maturity is available at the start of a standardization project, for example a standard developed by another organization, it is possible to omit certain stages. In the so-called "fast-track procedure," a document is submitted directly for approval as a draft international standard (DIS) to ISO member bodies (stage 4) or, if the document has been developed by an international standardizing body recognized by ISO Council, as a final draft international standard (FDIS, stage 5), without passing through the previous stages. 


\section{A4.9. ISO and IEC standards development $\operatorname{codes}^{68}$}

\begin{tabular}{|c|c|c|c|c|c|c|c|}
\hline \multirow[t]{3}{*}{ STAGE } & \multicolumn{7}{|l|}{ SUBSTAGE } \\
\hline & \multirow[b]{2}{*}{$\begin{array}{l}00 \\
\text { Registration }\end{array}$} & \multirow[b]{2}{*}{$\begin{array}{l}20 \\
\text { Start of main } \\
\text { action }\end{array}$} & \multirow[b]{2}{*}{$\begin{array}{l}60 \\
\text { Completion } \\
\text { of main } \\
\text { action }\end{array}$} & \multicolumn{4}{|c|}{$\begin{array}{l}90 \\
\text { Decision Substages }\end{array}$} \\
\hline & & & & $\begin{array}{l}92 \\
\text { Repeat an } \\
\text { earlier phase }\end{array}$ & $\begin{array}{l}93 \\
\text { Repeat } \\
\text { current phase }\end{array}$ & $\begin{array}{l}98 \\
\text { Abandon }\end{array}$ & $\begin{array}{l}99 \\
\text { Proceed }\end{array}$ \\
\hline $\begin{array}{l}00 \\
\text { Preliminary } \\
\text { stage }\end{array}$ & $\begin{array}{l}00.00 \\
\text { Proposal for } \\
\text { new project } \\
\text { received }\end{array}$ & $\begin{array}{l}00.20 \\
\text { Proposal for } \\
\text { new project } \\
\text { under review }\end{array}$ & $\begin{array}{l}00.60 \\
\text { Close of } \\
\text { review }\end{array}$ & & & $\begin{array}{l}00.98 \\
\text { Proposal for } \\
\text { new project } \\
\text { abandoned }\end{array}$ & $\begin{array}{c}00.99 \\
\text { Approval to } \\
\text { ballot proposal } \\
\text { for new project }\end{array}$ \\
\hline $\begin{array}{l}10 \\
\text { Proposal } \\
\text { stage }\end{array}$ & $\begin{array}{l}10.00 \\
\text { Proposal for } \\
\text { new project } \\
\text { registered }\end{array}$ & $\begin{array}{c}10.20 \\
\text { New project } \\
\text { ballot initiated }\end{array}$ & $\begin{array}{l}10.60 \\
\text { Close of } \\
\text { voting }\end{array}$ & $\begin{array}{l}10.92 \\
\text { Proposal } \\
\text { returned to } \\
\text { submitter for } \\
\text { further } \\
\text { definition }\end{array}$ & & $\begin{array}{c}10.98 \\
\text { New project } \\
\text { rejected }\end{array}$ & $\begin{array}{c}10.99 \\
\text { New project } \\
\text { approved }\end{array}$ \\
\hline $\begin{array}{l}20 \\
\text { Preparatory } \\
\text { stage }\end{array}$ & $\begin{array}{l}20.00 \\
\text { New project } \\
\text { registered in } \\
\text { TC/SC work } \\
\text { programme }\end{array}$ & $\begin{array}{l}20.20 \\
\text { Working draft } \\
\text { (WD) study } \\
\text { initiated }\end{array}$ & $\begin{array}{l}20.60 \\
\text { Close of } \\
\text { comment } \\
\text { period }\end{array}$ & & & $\begin{array}{l}20.98 \\
\text { Project } \\
\text { deleted }\end{array}$ & $\begin{array}{c}20.99 \\
\text { WD approved } \\
\text { for registration } \\
\text { as CD }\end{array}$ \\
\hline $\begin{array}{l}30 \\
\text { Committee } \\
\text { stage }\end{array}$ & $\begin{array}{c}\mathbf{3 0 . 0 0} \\
\text { Committee } \\
\text { draft }(C D) \\
\text { registered }\end{array}$ & $\begin{array}{c}30.20 \\
\mathrm{CD} \\
\text { study/ballot } \\
\text { initiated }\end{array}$ & $\begin{array}{l}30.60 \\
\text { Close of } \\
\text { voting/ } \\
\text { comment } \\
\text { period }\end{array}$ & $\begin{array}{l}30.92 \\
\text { CD referred } \\
\text { back to } \\
\text { Working } \\
\text { Group }\end{array}$ & & $\begin{array}{c}30.98 \\
\text { Project } \\
\text { deleted }\end{array}$ & $\begin{array}{c}30.99 \\
\text { CD approved } \\
\text { for registration } \\
\text { as DIS }\end{array}$ \\
\hline $\begin{array}{l}40 \\
\text { Enquiry } \\
\text { stage }\end{array}$ & $\begin{array}{c}\mathbf{4 0 . 0 0} \\
\text { DIS registered }\end{array}$ & $\begin{array}{l}40.20 \\
\text { DIS ballot } \\
\text { initiated: } 5 \\
\text { months }\end{array}$ & $\begin{array}{c}40.60 \\
\text { Close of } \\
\text { voting }\end{array}$ & $\begin{array}{c}\mathbf{4 0 . 9 2} \\
\text { Full report } \\
\text { circulated: } \\
\text { DIS referred } \\
\text { back to TC or } \\
\text { SC }\end{array}$ & $\begin{array}{l}40.93 \\
\text { Full report } \\
\text { circulated: } \\
\text { decision for } \\
\text { new DIS } \\
\text { ballot }\end{array}$ & $\begin{array}{l}40.98 \\
\text { Project } \\
\text { deleted }\end{array}$ & $\begin{array}{c}40.99 \\
\text { Full report } \\
\text { circulated: DIS } \\
\text { approved for } \\
\text { registration as } \\
\text { FDIS }\end{array}$ \\
\hline $\begin{array}{l}50 \\
\text { Approval } \\
\text { stage }\end{array}$ & $\begin{array}{c}50.00 \\
\text { FDIS } \\
\text { registered for } \\
\text { formal } \\
\text { approval }\end{array}$ & $\begin{array}{l}50.20 \\
\text { FDIS ballot } \\
\text { initiated: } 2 \\
\text { months. } \\
\text { Proof sent to } \\
\text { secretariat }\end{array}$ & $\begin{array}{l}50.60 \\
\text { Close of } \\
\text { voting. } \\
\text { Proof } \\
\text { returned by } \\
\text { secretariat }\end{array}$ & $\begin{array}{c}50.92 \\
\text { FDIS referred } \\
\text { back to TC or } \\
\text { SC }\end{array}$ & & $\begin{array}{c}50.98 \\
\text { Project } \\
\text { deleted }\end{array}$ & $\begin{array}{l}50.99 \\
\text { FDIS } \\
\text { approved for } \\
\text { publication }\end{array}$ \\
\hline $\begin{array}{l}60 \\
\text { Publication } \\
\text { stage }\end{array}$ & $\begin{array}{c}60.00 \\
\text { International } \\
\text { Standard } \\
\text { under } \\
\text { publication }\end{array}$ & & $\begin{array}{c}60.60 \\
\text { International } \\
\text { Standard } \\
\text { published }\end{array}$ & & & & \\
\hline $\begin{array}{l}90 \\
\text { Review } \\
\text { stage }\end{array}$ & & $\begin{array}{l}90.20 \\
\text { International } \\
\text { Standard } \\
\text { under } \\
\text { periodical } \\
\text { review }\end{array}$ & $\begin{array}{l}90.60 \\
\text { Close of } \\
\text { review }\end{array}$ & $\begin{array}{c}90.92 \\
\text { International } \\
\text { Standard to } \\
\text { be revised }\end{array}$ & $\begin{array}{c}90.93 \\
\text { International } \\
\text { Standard } \\
\text { confirmed }\end{array}$ & & $\begin{array}{c}90.99 \\
\text { Withdrawal of } \\
\text { International } \\
\text { Standard } \\
\text { proposed by } \\
\text { TC or SC }\end{array}$ \\
\hline $\begin{array}{l}95 \\
\text { Withdrawal } \\
\text { stage }\end{array}$ & & $\begin{array}{c}95.20 \\
\text { Withdrawal } \\
\text { ballot initiated }\end{array}$ & $\begin{array}{l}95.60 \\
\text { Close of } \\
\text { voting }\end{array}$ & $\begin{array}{c}95.92 \\
\text { Decision not } \\
\text { to withdraw } \\
\text { International } \\
\text { Standard }\end{array}$ & & & $\begin{array}{c}95.99 \\
\text { Withdrawal of } \\
\text { International } \\
\text { Standard }\end{array}$ \\
\hline
\end{tabular}

${ }^{68} \mathrm{http}$ ///www.iso.org/iso/stage codes.pdf (used with permission from ISO) 


\section{Annex 5. U.S.A. Laws Concerning NIST's Role in Standardization}

\section{A5.1 Trade Agreements Act of 197969}

\section{[Sec. 2532.] Federal standards-related activities}

No Federal agency may engage in any standards-related activity that creates unnecessary obstacles to the foreign commerce of the United States, including, but not limited to, standards-related activities that violate any of the following requirements:

(1) Nondiscriminatory treatment: Each Federal agency shall ensure, in applying standards-related activities with respect to any imported product, that such product is treated no less favorably than are like domestic or imported products, including, but not limited to, when applying tests or test methods, no less favorable treatment with respect to (A) the acceptance of the product for testing in comparable situations; (B) the administration of the tests incomparable situations; (C) the fees charged for tests; (D) the release of test results to the exporter, importer, or agents; (E) the siting of testing facilities and the selection of samples for testing; and $(F)$ the treatment of confidential information pertaining to the product.

(2) Use of international standards: (A) In general, except as provided in subparagraph (B) (ii), each Federal agency, in developing standards, shall take into consideration international standards and shall, if appropriate, base the standards on international standards. (B)Application of requirement. For purposes of this paragraph, the following apply: (i) International standards not appropriate. The reasons for which the basing of a standard on an international standard may not be appropriate include, but are not limited to, the following: (I) National security requirements. (II)The prevention of deceptive practices. (III) The protection of human health or safety, animal or plant life or health, or the environment. (IV) Fundamental climatic or other geographical factors. (V) Fundamental technological problems.(ii) Regional standards In developing standards, a Federal agency may, but is not required to, take into consideration any international standard promulgated by an international standards organization the membership of which is described in section 2571(6)(A)(ii) [1] of this title. (3) Performance criteria Each Federal agency shall, if appropriate, develop standards based on performance criteria, such as those relating to the intended use of a product and the level of performance that the product must achieve under defined conditions, rather than on design criteria, such as those relating to the physical form of the product or the types of material of which the product is made.

\section{[Sec. 2543.] Representation of United States interests before international standards organizations}

(a) Oversight and consultation: The Secretary concerned shall - (1) inform, consult, and coordinate with, the Trade Representative with respect to international standards-related activities identified under paragraph (2); (2) keep adequately informed regarding international standards-related activities and identify those that may substantially affect the commerce of the United States; and (3) carry out such

${ }^{69}$ Source: gsi.nist.gov/global/docs/TradeAgreementsAct1979.pdf 
functions as are required under subsections (b) and (c) of this section.

(b) Representation of United States interests by private persons: (1) Definitions, For purposes of this subsection - (A) Organization member, The term "organization member" means the private person who holds membership in a private international standards organization. (B) Private international standards organization, The term "private international standards organization" means any international standards organization before which the interests of the United States are represented by a private person who is officially recognized by that organization for such purpose. (2) In general, Except as otherwise provided for in this subsection, the representation of United States interests before any private international standards organization shall be carried out by the organization member. (3) Inadequate representation If the Secretary concerned, after inquiry instituted on his own motion or at the request of any private person, Federal agency, or State agency having an interest therein, has reason to believe that the participation by the organization member in the proceedings of a private international standards organization will not result in the adequate representation of United States interests that are, or may be, affected by the activities of such organization (particularly with regard to the potential impact of any such activity on the international trade of the United States), the Secretary concerned shall immediately notify the organization member concerned. During any such inquiry, the Secretary concerned may solicit and consider the advice of the appropriate representatives referred to in section 2547 of this title. (4) Action by organization member, If within the 90-day period after the date on which notification is received under paragraph (3) (or such shorter period as the Secretary concerned determines to be necessary in extraordinary circumstances), the organization member demonstrates to the Secretary concerned its willingness and ability to represent adequately United States interests before the private international standards organization, the Secretary concerned shall take no further action under this subsection. (5) Action by Secretary concerned, If - (A) within the appropriate period referred to in paragraph (4), the organization member does not respond to the Secretary concerned with respect to the notification, or does respond but does not demonstrate to the Secretary concerned the requisite willingness and ability to represent adequately United States interests; or (B) there is no organization member of the private international standards organization; the Secretary concerned shall make appropriate arrangements to provide for the adequate representation of United States interests. In cases where subparagraph (A) applies, such provision shall be made by the Secretary concerned through the appropriate organization member if the private international standards organization involved requires representation by that member.

(c) Representation of United States interests by Federal agencies: With respect to any international standards organization before which the interests of the United States are represented by one or more Federal agencies that are officially recognized by that organization for such purpose, the Secretary concerned shall - (1) encourage cooperation among interested Federal agencies with a view toward facilitating the development of a uniform position with respect to the technical activities with which the organization is concerned; (2) encourage such Federal agencies to seek information from, and to cooperate with, the affected domestic interests when undertaking such representation; and (3) not preempt the responsibilities of any Federal agency that has jurisdiction with respect to the activities undertaken by such organization, unless requested to do so by such agency. 


\section{A5.2 The National Technology Transfer and Advancement Act (NTTAA) of $1995^{70}$}

The National Technology Transfer and Advancement Act (NTTAA) directs Federal agencies with respect to their use of private sector standards and conformity assessment practices. The Act's objective is for Federal agencies to adopt private sector standards, wherever possible, in lieu of creating proprietary, non-consensus standards.

The Act directs the National Institute of Standards and Technology (NIST) to bring together Federal agencies, as well as State and local governments, to achieve greater reliance on voluntary standards and decreased dependence on in-house standards. Progress toward accomplishing NTTAA aims is summarized in annual reports prepared by NIST, in collaboration with the Interagency Committee on Standards Policy (ICSP).

\section{A5.3 OMB Circular No. A-11971}

OMB Circular A-119 establishes policies on Federal use and development of voluntary consensus standards and on conformity assessment activities. Pub. L. 104-113, the "National Technology Transfer and Advancement Act of 1995," codified existing policies in A-119, established reporting requirements, and authorized the National Institute of Standards and Technology to coordinate conformity assessment activities of the agencies. OMB is issuing this revision of the Circular in order to make the terminology of the Circular consistent with the National Technology Transfer and Advancement Act of 1995, to issue guidance to the agencies on making their reports to OMB, to direct the Secretary of Commerce to issue policy guidance for conformity assessment, and to make changes for clarity.

This Circular establishes policies to improve the internal management of the Executive Branch. Consistent with Section 12(d) of P.L. 104-113, the "National Technology Transfer and Advancement Act of 1995" (hereinafter "the Act"), this Circular directs agencies to use voluntary consensus standards in lieu of government-unique standards except where inconsistent with law or otherwise impractical. It also provides guidance for agencies participating in voluntary consensus standards bodies and describes procedures for satisfying the reporting requirements in the Act. The policies in this Circular are intended to reduce to a minimum the reliance by agencies on government-unique standards. These policies do not create the bases for discrimination in agency procurement or regulatory activities among standards developed in the private sector, whether or not they are developed by voluntary consensus standards bodies. Consistent with Section 12(b) of the Act, this Circular directs the Secretary of Commerce to issue guidance to the agencies in order to coordinate conformity assessment activities. This Circular replaces OMB Circular No. A-119, dated October 20, 1993.

\footnotetext{
${ }^{70}$ For more information: http://www.nist.gov/standardsgov/nttaa.cfm

${ }^{71}$ Source: http://www.nist.gov/standardsgov/omba119.cfm
} 


\section{Annex 6. MOU between ANSI and NIST72}

\section{A6.1 - 1.0 Purpose}

1.1 The underlying purpose of this Memorandum of Understanding (MOU) is to enhance and strengthen the national voluntary consensus standards system of the United States and to support continued U.S.A. competitiveness, economic growth, health, safety, and protection of the environment.

1.2 The National Institute of Standards and Technology (NIST) of the Department of Commerce and the American National Standards Institute (ANSI) agree on the need for a unified national approach to develop the best possible national and international standards, as reflected by the U.S.A. National Standards Strategy adopted by ANSI on August 31, 2000. This approach requires the best technical efforts of the United States in standards to ensure that our needs and interests are considered as national and international standards are developed, so that our international competitiveness is strengthened.

1.3 ANSI and NIST agree on the need for better communication within and between the private sector and Federal Government on voluntary standards and conformity assessment. There is a need to ensure the timely flow of relevant information about developments that affect those interests, and for improved liaison to facilitate decision-making and implement actions on standards and conformity assessment at the national and international levels. It is also critical that affected U.S.A. Government agencies are encouraged to contribute to the development and implementation of national and international voluntary standards.

This MOU is intended to facilitate and strengthen the recognition of ANSI as the representative of U.S.A. interests at the international level by all participants, improve domestic communication and coordination among both private and public sector parties in the United States on voluntary standards issues, and increase the effectiveness of U.S.A. Government agency participation in the national and international voluntary standards-setting process. It is also intended to facilitate the implementation by both parties of the National Standards Strategy.

\section{A6.2 - 2.0 Agreement}

2.1 ANSI is the recognized U.S.A. member body to the International Organization for Standardization (ISO), and, through the U.S.A. National Committee, to the International Electrotechnical Commission (IEC). It is also the U.S.A. member body to the Pacific Area Standards Congress (PASC), the Pan American Standards Commission (COPANT), and the International Accreditation Forum (IAF). As the U.S.A. representative to these bodies, ANSI shall participate in the related policy-making groups and committees of ISO, IEC, PASC, COPANT, and IAF, and shall convene delegations and appoint technical groups of a broad spectrum of experts to represent the United States voluntary standards community in the deliberations of relevant Boards, ad hoc groups, individual Technical Committees, and Working Groups of these organizations.

2.2 ANSI and NIST agree to provide a communications conduit between the voluntary, private sector, and government standards and conformity assessment interests. They will work together to ensure the

${ }^{72}$ Source: http://gsi.nist.gov/global/docs/ANSINISTMOU2000.pdf 
flow of relevant information about developments that affect those interests, and provide a liaison service to facilitate decision-making and implementation of needed actions at the national and international levels.

\section{A6.3 - 3.0 ANSI Responsibilities}

3.1 ANSI is responsible for ensuring that U.S.A. interests are represented at all policy and technical levels within ISO and IEC. It must convene accountable and competent delegations to develop and present U.S.A. positions for all ISO and IEC committees for which the United States holds Technical Advisory Groups, including ISO and IEC Council and ISO General Assembly committees. It will encourage strong and effective participation by appropriate U.S.A. stakeholders in all relevant committees, subcommittees, and working groups. ANSI will facilitate the building of consensus on standards issues and provide information about international standardization activities. ANSI is responsible for ensuring that the various U.S.A.-based Standards Developing Organizations (SDOs) are informed about ISO and IEC activities and given every opportunity to participate. ANSI shall take into account the positions of all affected interests and shall work with them to develop and promote a single, coordinated U.S.A. position in all activities of the international, non-treaty organizations referenced in 2.1 .

3.2 This MOU recognizes the desirability of direct cooperation among ANSI, SDOs, and any given Federal agency. Cooperation among domestic entities responsible for standards is essential to ensure the international competitiveness and effective representation of U.S.A. interests in private international standards organizations. The intent of this MOU is to recognize ANSI as the focal point for the exchange of information and development of representative U.S.A. positions for consideration at the international, non-treaty voluntary organizations referenced in 2.1.

3.3 ANSI accredits SDOs to develop and publish American National Standards in accordance with the principles of openness, balance of interests, due process, and consensus. ANSI works through its accredited standards development process to avoid duplication and overlap in proposed standards. ANSI is further responsible for approving proposed standards as American National Standards, and thereby meeting the obligations of the World Trade Organization Code of Good Practice.

3.4 ANSI accredits Management Systems Registrars and Product Certification Organizations in accordance with the relevant ISO Committee on Conformity Assessment guides and standards.

3.5 ANSI implements the National Standards Strategy through consultation with SDOs, industry, consumers, and government agencies.

\section{A6.4 - 4.0 NIST Responsibilities}

4.1 NIST's role, under the National Technology Transfer and Advancement Act of 1995 (Public Law [P.L.] 104-113) and as delegated by the Secretary of Commerce in the Office of Management and Budget Circular A-119 and the Trade Agreements Act of 1979 (P.L. 96-39), is to coordinate Federal activities in voluntary standards and to ensure adequate representation of U.S.A. interests in all relevant international standards organizations. NIST coordinates standards activities with responsible government agencies to use voluntary standards to the extent practicable, to participate appropriately in their development, and to ensure that they meet Federal agency needs. This MOU recognizes the responsibilities of individual 
agencies and does not preempt the responsibility of any Federal agency or take away any authority from any Federal agency to pursue its legislated regulatory programs.

4.2 NIST develops and implements means for facilitating, coordinating, and communicating information on voluntary standards activities among government agencies. NIST ensures that Federal agencies are aware of and support ANSI activities within ISO, IEC, or other private sector, international non -treaty standards and conformity assessment bodies such as COPANT, PASC, and the IAF. Finally, NIST will encourage agencies to use ANSI accredited SDOs to the extent feasible.

4.3 NIST facilitates information exchange between Federal agencies and the private sector on voluntary standards activities, using electronic means of communication to the extent feasible. It works with ANSI, Federal agencies, and the private sector to ensure that U.S.A. interests can participate appropriately in international standards activities to enhance U.S.A. international competitiveness. NIST provides technical experts to participate in the standards development process, both nationally and internationally, and encourages appropriate participation by other Federal agencies.

4.4 NIST recognizes accreditation programs for U.S.A. private sector conformity assessment activities in accordance with the National Voluntary Conformity Assessment System Evaluation Program (15 CFR Part 286). For laboratory accreditation programs, NIST accepts those laboratory accreditation bodies found competent by the National Cooperation for Laboratory Accreditation (NACLA) recognition process in accordance with the terms of the NIST-NACLA MOU, signed July 13, 2000.

\section{A6.5 - 5.0 Strategies}

5.1 NIST and ANSI will work on appropriate strategies for the success of the short- and long-term national goals for standards and conformity assessment, outlined in this MOU.

5.2 ANSI will support implementation of the National Standards Strategy and will meet U.S.A. obligations in ISO, IEC, COPANT, and PASC.

\section{A6.6 - 6.0 Other Agreements}

This MOU does not take precedence over any other MOUs that ANSI may have with individual Federal agencies such as the Occupational Safety and Health Administration, or that NIST may have with other private sector bodies.

\section{A6.7 - 7.0 Annual Meeting}

The Director of NIST, ANSI's Chairman of the Board, and ANSI's President and Chief Executive Officer agree that they and other appropriate representatives from their organizations shall meet annually to review this MOU and its implementation.

\section{A6.8 - 8.0 Termination}

Either party may terminate this agreement with written notice to the other party. 